\title{
Metamorphic fingerprints of Fe-rich chromitites from the Eastern Pampean Ranges, Argentina
}

\section{Evidencias del metamorfismo en cromititas ricas en Fe del oriente de las Sierras Pampeanas, Argentina}

Vanessa Colás ${ }^{1, *}$, Ignacio Subías ${ }^{2 \dagger,}$, José María González-Jiménez ${ }^{3}$, Joaquín A. Proenza ${ }^{4}$, Isabel Fanlo², Antoni Camprubí ${ }^{1}$, William L. Gri in ${ }^{5}$, Fernando Gervilla ${ }^{3,6}$, Suzanne Y. O’Reilly ${ }^{5}$, Mónica F. Escayola

Instituto de Geología, Universidad Nacional Autónoma de México, Ciudad Universitaria, Coyoacán, 04510, CDMX, México.

${ }^{2}$ Universidad de Zaragoza, Departamento de Ciencias de la Tierra, Pedro Cerbuna 12, 50009 Zaragoza, Spain.

$\dagger^{\dagger}$ Rest in peace.

${ }^{3}$ Departamento de Mineralogía y Petrología, Universidad de Granada, Facultad de Ciencias, Avenida. Fuentenueva s/n, 18002 Granada, Spain.

${ }^{4}$ Departament de Mineralogia, Petrologia i Geologia Aplicada, Universitat de Barcelona. C/Martí i Franquès s/n, 08028 Barcelona, Spain.

ARC Centre of Excellence for Core to Crust Fluid Systems (CCFS) and GEMOC National Key Centre, Department of Earth and Planetary Sciences, Macquarie University, Sydney, NSW 2109, Australia.

${ }^{6}$ Instituto Andaluz de Ciencias de la Tierra (Universidad de Granada-CSIC), Avenida las Palmeras 4, Armilla, 18100 Granada, Spain.

${ }^{7}$ Instituto de Ciencias Polares y Ambientales ICPA, Universidad de Tierra del Fuego-CONICET, Fueguia Basket 251, 9410-Ushuaia, Tierra del Fuego, Argentina.

* Corresponding author: (V. Colás

vcolas86@gmail.com

\section{How to cite this article:}

Colás, V., Subías, I., González-Jiménez, J. M., Proenza, J. A., Fanlo, I., Camprubí, A., Griffin, W. L., Gervilla, F., O'Reilly, S. Y., Escayola, M., 2020, Metamorphic fingerprints of Fe-rich chromitites from the Eastern Pampean Ranges, Argentina: Boletín de la Sociedad Geológica Mexicana, 72 (3), A080420. http://dx.doi. org/10.18268/BSGM2020v72n3a080420

Manuscript received: September 27, 2019 Corrected manuscript received: April 1, 2020 Manuscript accepted: April 8, 2020

Peer Reviewing under the responsibility of Universidad Nacional Autónoma de México

This is an open access article under the CC BY-NC-SA license(https://creativecommons.org/licenses/by-nc-sa/4.0/)

\section{ABSTRACT}

Chromitites hosted in the serpentinized harzburgite bodies from Los Congos and Los Guanacos (Eastern Pampean Ranges, north Argentina) record a complex metamorphic evolution. The hydration of chromitites during the retrograde metamorphism, their subsequent dehydration during the prograde metamorphism and the later-stage cooling, have resulted in a threefold alteration of chromite: i) Type I is characterized by homogeneous $\mathrm{Fe}^{3+}$ - and Cr-rich chromite; ii) Type II chromite contains exsolved textures that consist in blebs and fine lamellae of a magnetite-rich phase hosted in a spinel-rich phase; iii) Type III chromite is formed by variable proportions of magnetite-rich and spinel-rich phases with symplectitic texture. Type I chromite shows lower $\mathrm{Ga}$ and higher Co, $\mathrm{Zn}$ and Mn than magmatic chromites from chromitites in suprasubduction zone ophiolites as a consequence of the redistribution of these elements between $\mathrm{Fe}^{3+}$-rich non-porous chromite and silicates during the prograde metamorphism. Whereas, the spinel-rich phase in Type III chromite is enriched in $\mathrm{Co}, \mathrm{Zn}, \mathrm{Sc}$, and $\mathrm{Ga}$, but depleted in $\mathrm{Mn}, \mathrm{Ni}, \mathrm{V}$ and $\mathrm{Ti}$ with respect to the magnetite-rich phase, due to the metamorphic cooling from high-temperature conditions. The pseudosection calculated in the fluid-saturated FCrMACaSH system, and contoured for $\mathrm{Cr} \#$ and $\mathrm{Mg} \#$, allows us to constrain the temperature of formation of $\mathrm{Fe}^{3+}$-rich non-porous chromite by the diffusion of magnetite in $\mathrm{Fe}^{2+}$-rich porous chromite at $<500$ ${ }^{\circ} \mathrm{C}$ and 20 kbar. The subsequent dehydration of $\mathrm{Fe}^{3+}$-rich non-porous chromite by reaction with antigorite and chlorite formed Type I chromite and $\mathrm{Mg}$-rich olivine and pyroxene at $>800^{\circ} \mathrm{C}$ and $10 \mathrm{kbar}$. The ultimate hydration of silicates in Type I chromite and the exsolution of Type II and Type III chromites would have started at $\sim 600^{\circ} \mathrm{C}$. These temperatures are in the range of those estimated for ocean floor serpentinization $\left(<300{ }^{\circ} \mathrm{C}\right.$ and $\left.<4 \mathrm{kbar}\right)$, the regional prograde metamorphism in the granulite facies (800 ${ }^{\circ} \mathrm{C}$ and $<10 \mathrm{kbar}$ ), and subsequent retrogression to the amphibolite facies $\left(600{ }^{\circ} \mathrm{C}\right.$ and $\left.4-6.2 \mathrm{kbar}\right)$ in the host ultramafic rocks at Los Congos and Los Guanacos. A continuous and slow cooling from granulite to amphibolite facies produced the exsolution of spinel-rich and magnetite-rich phases, developing symplectitic textures in Type III chromite. However, the discontinuous and relatively fast cooling produced the exsolution of magnetite-rich phase blebs and lamellae within Type II chromite. The P-T conditions calculated in FCrMACaSH system and the complex textural and geochemical fingerprints showed by Type I, Type II and Type III chromites leads us to suggest that continent-continent collisional orogeny better records the fingerprints of prograde metamorphism in ophiolitic chromitites.

Keywords: altered chromite, minor and trace elements, thermodynamic modelling, prograde metamorphism, Eastern Pampean Ranges, Argentina.

\section{RESUMEN}

Las cromititas incluidas en los cuerpos de harzburgita serpentinizada de Los Congos y Los Guanacos (Sierras Pampeanas Orientales, norte de Argentina) registran una evolución metamórfica compleja. La hidratación de las cromititas durante el metamorfismo retrógrado, su posterior deshidratación durante el metamorfismo prógrado y el subsecuente enfriamiento ha dado como resultado la formación de tres tipos de cromita alterada: i) Tipo I, caracterizada por una cromita homogénea y rica en $\mathrm{Fe}^{3+}$ y $\mathrm{Cr}$; ii) cromita Tipo II, con texturas de exsolución que consisten en gránulos y lamelas finas de una fase rica en magnetita alojada en una fase rica en espinela; iii) cromita Tipo III, formada por proporciones variables de las fases ricas en magnetita y espinela con textura simplectítica. La cromita Tipo I muestra menor Ga pero mayor $\mathrm{Co}, Z_{n}$ y Mn que las cromitas magmáticas de las cromititas ofioliticas en zonas de suprasubducción como consecuencia de la redistribución de estos elementos entre la cromita no porosa rica en $\mathrm{Fe}^{3+}$ y los silicatos durante el metamorfismo prógrado. En cambio, la fase rica en espinela en la cromita Tipo III está enriquecida en Co, Zn, Scy $G a$, pero empobrecida en $M n, \mathcal{N i}, V y$ Ti respecto a la fase rica en magnetita debido al enfriamiento metamórfico desde condiciones de alta temperatura. La pseudosección calculada en el sistema FCrMACaSH saturado de agua y contorneada para el \#Cry \#Mg, nos permite restringir la temperatura de formación de la cromita no porosa rica en $\mathrm{Fe}^{3+}$ debido a la difusión de la magnetita en la cromita porosa rica en $\mathrm{Fe}^{2+} a<500{ }^{\circ} \mathrm{C}$ y 20 kbar. La posterior deshidratación de la cromita no porosa rica en $\mathrm{Fe}^{3+}$ formó por reacción con antigorita y clorita, cromita Tipo I y olivino y piroxeno ricos en Mg a $>800^{\circ} \mathrm{C}$ y 10 kbar. La hidratación final de los silicatos en la cromita Tipo I y la exsolución de las cromitas Tipo II y Tipo III pudo haber comenzado a $\sim 600^{\circ} \mathrm{C}$. Estas temperaturas están en el rango de las estimadas para la serpentinización de fondo oceánico $\left(<300{ }^{\circ} \mathrm{Cy}<4 \mathrm{kbar}\right)$, el metamorfismo regional prógrado en facies de granulita $\left(800^{\circ} \mathrm{Cy}<10 \mathrm{kbar}\right), y$ la posterior retrogresión a facies de anfibolita $\left(600^{\circ} \mathrm{C}\right.$ y $\left.4-6.2 \mathrm{kbar}\right)$ de las rocas ultramáficas encajantes en Los Congos y Los Guanacos. Un enfriamiento continuo y lento de facies de granulita a anfibolita produjo la exsolución de las fases ricas en espinela y magnetita, desarrollando texturas simpléctíticas en la cromita Tipo III. Sin embargo, el enfriamiento discontinuo y relativamente rápido produjo la exsolución de los gránulos y las lamelas de la fase rica en magnetita dentro de la cromita Tipo II. Las condiciones P-T calculadas en el sistema FCrMACaSH y las complejas texturas y firmas geoquimicas mostradas por las cromitas Tipo I, Tipo II y Tipo III nos permiten sugerir que las orogenias que implican la colisión continente-continente registran mejor las firmas del metamorfismo prógrado en las cromititas ofiolíticas.

Palabras clave: cromita alterada, elementos menores y traza, modelización termodinámica, metamorfismo prógrado, Sierras Pampeanas Orientales, Argentina. 


\section{Introduction}

Chromitites chiefly consist of $\mathrm{Cr}$ - and Al-rich chromite (generally, $>80 \mathrm{vol} . \%$ of chromite; Arai and Miura, 2016), which represent the main reservoir of chromium in nature. Chromitite orebodies large enough for mining are spatially associated with mafic and ultramafic rocks and their serpentinized equivalents, and are generally found in: i) continental layered intrusions forming stratiform chromitites, and ii) different parts of the oceanic ophiolitic sequences as a "podiform" or "stratiform" chromitites (e.g., Leblanc and Nicolas, 1992; Stowe, 1994; González-Jiménez et al., 2014 and references therein). Besides their economic importance, chromitites are also scientifically relevant because the composition and microstructural features of chromite, and the mineralogy of their inclusions (i.e., ultra-high pressure, super-reducing and continental crust minerals) provide valuable information about the nature, evolution and geodynamics of the Earth's lithosphere (e.g., Dick and Bullen, 1984; Arai, 1992; Barnes and Roeder, 2001; Kamenetsky et al. 2001; Rollinson, 2008; González-Jiménez et al., 2014; Arai and Miura, 2016; Griffin et al., 2016; Xiong et al. 2017; Farré-de-Pablo et al., 2019; Pujol-Solà et al., 2018; Tanner et al., 2019).

Mineralogical, geochemical and thermodynamic studies performed in "meta-chromitite bodies" from suprasubduction zone ophiolitic sections in Tehuitzingo and Loma Baya in southern Mexico (Proenza et al., 2004; Ortiz-Hernández et al., 2006; González-Mancera et al., 2009; González-Jiménez et al., 2015, 2017; Colás et al., 2019; Farré-de-Pablo et al., 2019), Tapo in Peru (Castroviejo et al., 2009; Tassinari et al., 2011; Colás et al., 2017), and La Cabaña in Chile (Barra et al., 2014; González-Jiménez et al., 2016; Plissart et al., 2019) suggest that during their exhumation the primary silicates (olivine and pyroxene) are transformed by serpentine and chlorite, while the magmatic chromites are replaced by $\mathrm{Fe}^{2+}$-rich porous and/or $\mathrm{Fe}^{3+}$-rich non-porous chromite. This metamorphic alteration takes place in pres- ence of reducing/oxidizing $\left(\mathrm{Fe}^{3+}-\right) \mathrm{SiO}_{2}$-rich and $\mathrm{MgO}$-poor fluids, at temperatures below 700 ${ }^{\circ} \mathrm{C}$ (e.g., Gervilla et al., 2012; Barra et al., 2014; Colás et al., 2014, 2017, 2019; González-Jiménez et al., 2016, 2018; Farré-de-Pablo et al., 2019). In contrast, the dehydration of previously hydrated chromitites by contact metamorphism turns back the metamorphic reaction, forming a non-porous chromite with a composition close to primary chromite and $\mathrm{Mg}$-rich olivine, at temperatures above $550-600{ }^{\circ} \mathrm{C}$ (González-Jiménez et al., 2015). The analysis of chromite using LA-ICP-MS have revealed that during metamorphism the cores of chromite grains may retain their initial magmatic signature, particularly during the formation of $\mathrm{Fe}^{2+}$-rich porous chromite (Barra et al., 2014; Colás et al., 2014, 2017, 2019; González-Jiménez et al., 2015, 2016; Kapsiotis et al., 2018; Yu et al., 2019). Meanwhile, several minor and trace elements (i.e., V, Sc, Ga, Ti, Ni, Zn, Co and Mn) may pervade into the cores during the formation of $\mathrm{Fe}^{3+}$-rich non-porous chromite (González-Jiménez et al., 2016, Colás et al., 2019). This demonstrates that minor and trace elements are mobile during the alteration of chromitite bodies and, therefore, they define fingerprints of retrograde hydrous metamorphism. However, this issue has never been examined on chromitites affected by prograde regional metamorphism.

In this research work we provide a detailed study including petrographic observations, analysis of major, minor and trace element composition of chromites, coupled with thermodynamic modelling for chromitite bodies from Los Congos and Los Guanacos ultramafic massifs in the Eastern Pampean Ranges, northern Argentina (Escayola et al., 2004; Proenza et al., 2008). These ultramafic massifs are among the few known examples of suprasubduction zone ophiolites in Latin America that contain a mantle section with chromitites that have experienced high-temperature metamorphism as a result of a continent-continent collisional orogeny (e.g., Escayola et al., 2007; Collo et al., 2009). Therefore, this regional context is important to evaluate the geochemical finger- 
prints of prograde metamorphism in chromites from ophiolitic chromitites.

\section{Geological setting}

The Eastern Pampean Ranges constitute the easternmost exposure of the metamorphic basement of the Central Andes, in northern Argentina (Figure 1), and represent an accretionary orogen developed during the Neoproterozoic-Early Cambrian at the SW paleo-Pacific margin of Gondwana (e.g., Escayola et al., 2007; Collo et al., 2009). The Eastern Pampean Ranges are mainly composed of low- to high-grade metamorphic sedimentary and igneous units that are essentially constituted by garnet-biotite gneiss and biotite schists, with minor occurrence of marbles, phyllites, amphibolites and ultramafic rocks of ophiolitic affinity (e.g., Escayola et al., 1996, 2004, 2007; Rapela et al., 1998, 2016). These units were locally migmatized (i.e., San Carlos Massif and Yacanto Group; Martino et al., 1995; Siegesmund et al., 2010; Guereschi and Martino, 2008) and intruded by Early Cambrian granitoids (Rapela et al., 1998; Escayola et al., 2007) (Figure 1). All the basement units were intruded by Ordovician and Devonian metaluminous to peraluminous granitoids (e.g., Rapela et al., 1998, 2018; Pinotti et al., 2002; Geuna et al., 2008) and were locally covered by Cretaceous volcanic-sedimentary sequences and Cenozoic volcanic rocks (Ramos et al., 1991; Kay and Gordillo, 1994; Lagorio et al., 2016 and references therein) (Figure 1).

The ultramafic bodies are arranged into two NW-SE belts associated with ductile shear zones that crosscut the migmatitic massifs, gneisses and schists (Figure 1). Los Congos and Los Guanacos ultramafic massifs (up to $1.3 \mathrm{~km}$ long and $0.7 \mathrm{~km}$ wide) are merely $6 \mathrm{~km}$ away of each other, and outcrop in the southwestern ophiolitic belt of the Eastern Pampean Ranges, along the Sierra de Comechingones (Figures 1 and 2). Such massifs consist of partly to strongly serpentinized harzburgites that host chromitite bodies, which are accompanied by lenses of dunites and impregnated peridotites, and are cut by pyroxenite, gabbro and basalt dikes $(0.5$ to $1 \mathrm{~m}$ thick and several meters long) in Los Guanacos massif (Escayola et al., 2004, 2007; Proenza et al., 2008). These lithologies are in tectonic contact with metapelites, tonalitic gneisses and marbles (Figure 2), and were considered as a fragment of a Neoproterozoic (647 \pm 77 Ma; Escayola et al., 2007) back-arc ophiolite sequence represented by: i) the porphyroclastic harzburgite tectonites in Los Congos massif, and ii) the Moho Transition Zone (MTZ) in Los Guanacos massif (Escayola et al., 2004, 2007; Ramos et al., 2010).

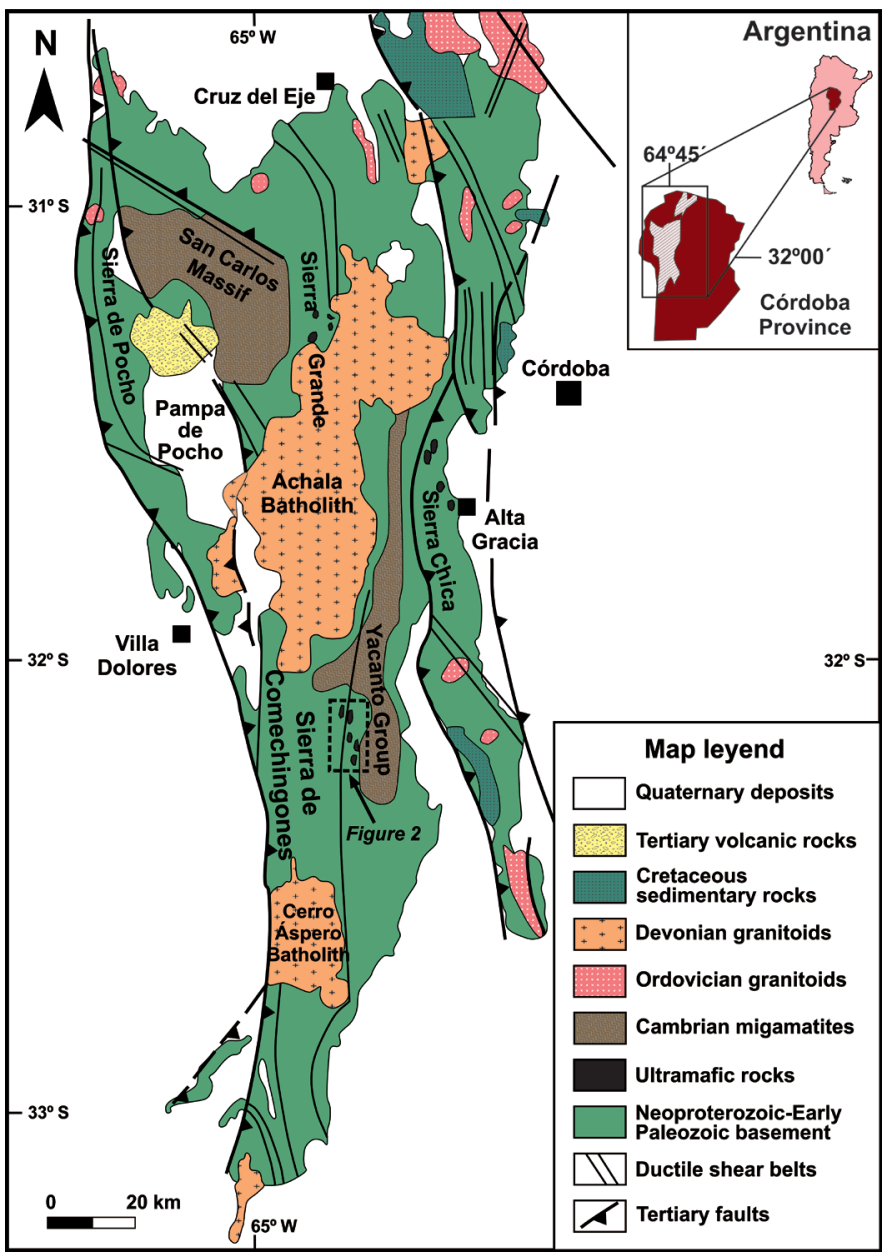

Figure 1 Simplified geological map of the Eastern Pampean Ranges (modified from Martino, 2003 and Siegesmund et al., 2010) showing the location of Los Congos and Los Guanacos ultramafic massifs hosting the chromitite bodies investigated in this work. 


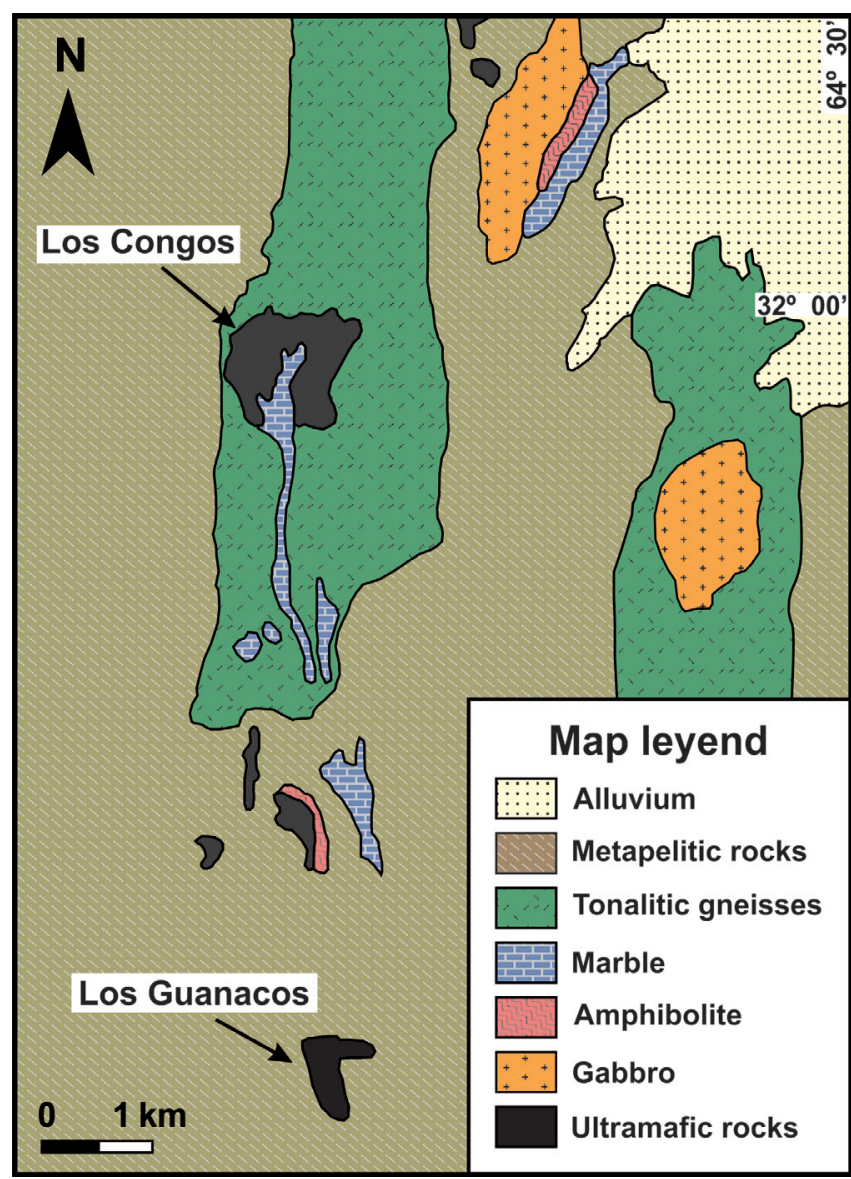

Figure 2 Simplified geological map of Los Congos and Los Guanacos ultramafic massifs (modified from Escayola et al., 2004).

Based on mineral assemblages and textures, Escayola et al. $(1996,2004)$ distinguished four metamorphic events in the ultramafic rocks of the Sierra de Comechingones. The first event of metamorphism occurred at ocean floor conditions, and is characterized by the replacement of primary olivine by lizardite/chrysotile with mesh and pseudomorphic textures, and by the replacement of pyroxene by bastite $\left(<300{ }^{\circ} \mathrm{C}\right.$ and $<4$ kbar $)$. During the second event, the regional prograde metamorphism produced the transformation of lizardite to antigorite along with olivine-bearing assemblages at $780-800{ }^{\circ} \mathrm{C}$ and $<10$ kbar. The third event of metamorphism led to the retrogression of olivine to anthophyllite and antigorite+brucite at $500{ }^{\circ} \mathrm{C}$. The last metamorphic event is related to the formation of veins of talc+chrysotile during a low-temperature hydrothermal event. The second and the third metamorphic events recorded in the ultramafic rocks were associated with the collisional episode and the subsequent decompression and exhumation of the accretionary orogeny.

These metamorphic events were also recorded in the basement of Eastern Pampean Ranges. The second stage of metamorphism occurred under granulite facies conditions, peaking at $800 \pm 150$ ${ }^{\circ} \mathrm{C}$ and $7.5 \pm 5 \mathrm{kbar}$, and the retrogression to the amphibolite facies occurred at $600{ }^{\circ} \mathrm{C}$ and $4.5 \pm$ $1.5 \mathrm{kbar}$ in gneisses, migmatites and granulites from the Sierra de Comechingones (Otamendi et al., 1999, 2004, 2005). However, higher pressure metamorphic peak conditions $\left(810 \pm 50{ }^{\circ} \mathrm{C}\right.$ and $8.6 \pm 0.8 \mathrm{kbar})$, and the highest temperature for the amphibolite facies overprint $\left(715 \pm 15{ }^{\circ} \mathrm{C}\right.$ and $4 \pm 0.5 \mathrm{kbar}$ ) were estimated in metagabbros, garnet migmatites and tonalities from the Sierra Chica and Sierra Grande (Rapela et al., 1998). In addition, Martino et al. (2010) reported similar metamorphic peak conditions $\left(804 \pm 36{ }^{\circ} \mathrm{C}\right.$ and $7.9 \pm 0.7 \mathrm{kbar}$ ) on garnet gneisses of the Sierra Chica, but recorded a lower temperature and higher pressure overprint $\left(649 \pm 61{ }^{\circ} \mathrm{C}\right.$ and $6.2 \pm$ 1 kbar) than Rapela et al. (1998).

The chromitite samples collected for this study were obtained from six chromitite bodies from Los Congos and Los Guanacos ultramafic massifs (Proenza et al., 2008). Chromitite bodies occurred as small pods and layers, few tens of meters long and less than $5 \mathrm{~m}$ thick, and are enveloped by dunites of variable thickness, enclosed in metaharzburgites, and occasionally crosscut by pyroxenite, gabbro and dolerite dykes (Escayola et al. 2004; Proenza et al., 2008).

\section{Analytical methods}

Selected chromite grains that preserved the textural varieties described by Colás et al. (2016) were imaged using a scanning electron microscope (SEM) model JEOL SM 6400 SEM equipped with energy-dispersive spectrometry and back-scattered electron (BSE) detectors available at the 
Universidad de Zaragoza (Spain). Additional BSE images of chromites were performed with a Swift-ED Hitachi TM-1000 Environmental Scanning Electron Microscope (ESEM) available at the Laboratorio de Petrografía y Microtermometría of the Instituto de Geofisica, Universidad Nacional Autónoma de México (Mexico).

Major-element composition of the different phases in the textural varieties of chromite has been analysed using a CAMECA SX-100 electron microprobe (EMPA) available at the Geochemical Analysis Unit of the CGFS/GEMOG, Macquarie University (Australia) under the following working conditions: $20 \mathrm{kV}$ acceleration voltage, $20 \mathrm{nA}$ beam current and 2-3 $\mu \mathrm{m}$ beam size. Peak counting times were $10 \mathrm{~s}$ for $\mathrm{Cr}, \mathrm{Fe}, \mathrm{Ti}, \mathrm{V}, \mathrm{Mn}, \mathrm{Zn}$, and $\mathrm{Ni}, 20 \mathrm{~s}$ for $\mathrm{Mg}$, and $30 \mathrm{~s}$ for $\mathrm{Al}$. Natural and synthetic standards used were $\mathrm{MgO}(\mathrm{Mg})$, olivine $(\mathrm{Si})$, kyanite $(\mathrm{Al})$, sphalerite $(\mathrm{Zn})$, magnetite $(\mathrm{Fe})$, rhodonite $(\mathrm{Mn})$, rutile $(\mathrm{Ti})$ and pure metals for $\mathrm{Ni}$, Cr and V. Matrix correction were applied followed the method by Pouchou and Pichoir (1991). Additional chromite analyses were performed using a CAMECA SX-50 EMPA instrument belonging to the Centres Científics i Tecnològics of the Universitat de Barcelona (CCiTUB, Spain). The analytical conditions were $20 \mathrm{kV}$ accelerating voltage, $20 \mathrm{n} \AA$ beam current, $3 \mu \mathrm{m}$ beam diameter, and counting time of $20 \mathrm{~s}$ for $\mathrm{Mg}, \mathrm{Al}, \mathrm{Si}, \mathrm{Ti}$, and $\mathrm{Cr}$, and $30 \mathrm{~s}$ for V, Mn, Fe, Ni, Zn and Co. Calibration standards were natural and synthetic materials: periclase $(\mathrm{Mg})$, corundum $(\mathrm{Al})$, diopside $(\mathrm{Si})$, rutile (Ti), $\mathrm{Cr}_{2} \mathrm{O}_{3}(\mathrm{Cr})$, rhodonite $(\mathrm{Mn})$, magnetite $(\mathrm{Fe})$, $\mathrm{NiO}(\mathrm{Ni})$, sphalerite $(\mathrm{Zn})$ and pure metals for $\mathrm{V}$ and Co. The correction procedure XPP (Pouchou and Pichoir, 1991) was used to convert specimen intensity ratios into concentrations. The chemical data for chromite were stoichiometrically recalculated in order to distinguish $\mathrm{FeO}$ from $\mathrm{Fe}_{2} \mathrm{O}_{3}$ according to the procedure described by Droop (1987).

The quantitative analyses of silicates were carried out using a JEOL JXA-8230 EMPA instrument available at the CCiTUB (Spain) under the following working conditions: $20 \mathrm{kV}$ acceleration voltage, $20 \mathrm{nA}$ beam current, $2 \mu \mathrm{m}$ beam diameter and counting time of $10 \mathrm{~s}$ per element. The standards used are albite $(\mathrm{Na})$, periclase $(\mathrm{Mg})$, corundum $(\mathrm{Al})$, diopside $(\mathrm{Si})$, wollastonite $(\mathrm{Ca})$, rutile $(\mathrm{Ti}), \mathrm{Cr}_{2} \mathrm{O}_{3}(\mathrm{Cr})$, rhodonite $(\mathrm{Mn})$, magnetite $(\mathrm{Fe})$, and sphalerite $(\mathrm{Zn})$. The correction procedure XPP (Pouchou and Pichoir, 1991) was used to convert specimen intensity ratios into concentrations. Additional silicates were analyzed using a JEOL JXA-8900R EPMA instrument available at the Laboratorio Universitario de Petrología of the Instituto de Geofísica, Universidad Nacional Autónoma de México (Mexico). The analytical conditions were $20 \mathrm{kV}$ accelerating voltage, 20 $\mathrm{n} \AA$ beam current, and $1 \mu \mathrm{m}$ beam diameter. Peak counting times were $40 \mathrm{~s}$ for $\mathrm{Al}, \mathrm{Ca}, \mathrm{Cr}, \mathrm{Fe}, \mathrm{Mg}$, $\mathrm{Mn}, \mathrm{Ni}$, Si and Ti, and $10 \mathrm{~s}$ for Na and K. ZAF corrections were applied online. The calibration was performed using natural and synthetic standards: albite $(\mathrm{Na})$, diopside $(\mathrm{Mg})$, kaesurtite $(\mathrm{Al})$, diopside ( $\mathrm{Si}, \mathrm{Ca}$ and $\mathrm{Cr}$ ), ilmenite ( $\mathrm{Ti}$ and $\mathrm{Fe}$ ), olivine $(\mathrm{Ni}$ and $\mathrm{Mn}$ ). All EMPA data of chromite and silicates are listed in Appendices 1 and 2, respectively.

Minor- and trace-element compositions of the different phases in chromite grains were analysed using a New Wave UP 266 laser system connected to an Agilent 7500cs ICP-MS available at the Geochemical Analysis Unit of the CGFS/GEMOC, Macquarie University (Australia), following the method described by Colás et al. (2016). For this study, the LA-ICP-MS analyses of chromite were focused on the ${ }^{45} \mathrm{Sc},{ }^{47} \mathrm{Ti},{ }^{51} \mathrm{~V},{ }^{55} \mathrm{Mn},{ }^{59} \mathrm{Co},{ }^{60} \mathrm{Ni},{ }^{66} \mathrm{Zn}$ and ${ }^{69} \mathrm{Ga}$ masses, and are listed in Appendix 3.

The thermodynamic modelling of phase relations during the alteration of chromite was performed using the Perple_X 6.8.3 software (Connolly, 2009), and the internally consistent thermodynamic database extended to include Cr-bearing phases (Holland and Powell, 1998, revised in 2002; cr_hp02ver.dat). The components considered to perform the pseudosection calculations of chromitite sample were computed in the close system $\mathrm{FeO}-\mathrm{Fe}_{2} \mathrm{O}_{3}-\mathrm{Cr}_{2} \mathrm{O}_{3}-\mathrm{MgO}-$ $\mathrm{Al}_{2} \mathrm{O}_{3}-\mathrm{CaO}-\mathrm{SiO}_{2}-\mathrm{H}_{2} \mathrm{O}$ (FCrMACaSH), and the 
solid solutions were Cr-spinel (Colás et al., 2019), antigorite (Padrón-Navarta et al., 2013), magnetite (Sack and Ghiorso, 1991b), olivine, chlorite, orthopyroxene and clinopyroxene (Holland and Powell, 1998). All other minerals involved in the calculations are pure phases. The $\mathrm{Fe}_{2} \mathrm{O}_{3}$ component in the textural varieties of chromite was considered as the magnetite solid solution phases, while the Cr-bearing chlorite was not considered because of the lack of experimental data on the mixing parameters for $\mathrm{Al}$ and $\mathrm{Cr}$ in this mineral.

\section{Petrography and chemistry of chromitite orebodies}

\subsection{GHROMITE}

The chromitite bodies consist of massive $>80$ vol. $\%$ chromite), semi-massive (50-80 vol. $\%$ chromite), and to a lesser extent, disseminated (30-50 vol. $\%$ chromite) textures. These chromitites were intensely modified by metamorphism, which has produced the three textural varieties of chromites defined by Colás et al. (2016) (Table 1; Figure 3). Type I chromite, without exsolved phases and optically homogeneous (Figure 3a), shows a trend of increase of $\mathrm{Cr} \#[\mathrm{Cr} /(\mathrm{Cr}+\mathrm{Al})$ atomic ratio] coeval with a decrease of $\mathrm{Mg} \#\left[\mathrm{Mg} /\left(\mathrm{Mg}+\mathrm{Fe}^{2+}\right)\right.$ atomic ratio] displaced at lower $\mathrm{Mg} \#$ from massive $(\mathrm{Mg} \#=0.52-0.68$ and $\mathrm{Cr} \#=0.47-0.72)$, semi-massive $(\mathrm{Mg} \#=0.48-0.55$ and $\mathrm{Cr} \#=0.60$ $0.73)$ to disseminated $(\mathrm{Mg} \#=0.42-0.52$ and $\mathrm{Cr} \#$ $=0.55-0.63$ ) chromitites (Table 1; Figure 4a to 4c). $\mathrm{The} \mathrm{Fe}^{3+} /\left(\mathrm{Fe}^{3+}+\mathrm{Fe}^{2+}\right)$ ratio varies from 0.43 to 0.54 in Type I chromite from massive and disseminated chromitites, but is lower in Type I chromite from semi-massive chromitites $\left(\mathrm{Fe}^{3+} /\left(\mathrm{Fe}^{3+}+\mathrm{Fe}^{2+}\right)=0.24\right.$ 0.27) (Table 1; Figure 4a to 4c). Type II chromite shows a magnetite-rich phase $(\mathrm{Mg} \#=0.21-0.23$, $\mathrm{Cr} \#=0.85-0.87$, and $\mathrm{Fe}^{3+} /\left(\mathrm{Fe}^{3+}+\mathrm{Fe}^{2+}\right)=0.62-$ $0.63)$ that forms irregular blebs randomly distributed along the rims or linear strings, and fine lamellae with apparent crystallographic control hosted in a spinel-rich phase $(\mathrm{Mg} \#=0.56-0.63$,
$\mathrm{Cr} \#=0.50-0.54$, and $\mathrm{Fe}^{3+} /\left(\mathrm{Fe}^{3+}+\mathrm{Fe}^{2+}\right)=0.43-$ 0.52 ) (Table 1; Figures $3 \mathrm{c}$ and $4 \mathrm{~d}$ to $4 \mathrm{f}$ ). Type III chromite, with symplectitic texture, is composed of variable proportions of magnetite-rich $(\mathrm{Mg} \#=$ 0.29-0.33, $\mathrm{Cr} \#=0.76-0.79$, and $\mathrm{Fe}^{3+} /\left(\mathrm{Fe}^{3+}+\mathrm{Fe}^{2+}\right)$ $=0.62-0.64)$ and spinel-rich $(\mathrm{Mg} \#=0.64-0.73$, $\mathrm{Cr} \#=0.41-0.43$, and $\mathrm{Fe}^{3+} /\left(\mathrm{Fe}^{3+}+\mathrm{Fe}^{2+}\right)=0.40-$ 0.54 ) phases (Table 1; Figures $3 \mathrm{~d}$ and $4 \mathrm{~d}$ to $4 \mathrm{f}$ ). This chromite prior to exsolution have similar $\mathrm{Mg \#} \mathrm{(0.44-0.50)} \mathrm{and} \mathrm{Cr \#} \mathrm{(0.54-0.59),} \mathrm{but} \mathrm{higher}$ $\mathrm{Fe}^{3+} /\left(\mathrm{Fe}^{3+}+\mathrm{Fe}^{2+}\right)(0.60-0.61)$ than Type I chromite from disseminated chromitites $(\mathrm{Mg} \#=0.42-0.52$, $\mathrm{Cr} \#=0.55-0.63$, and $\mathrm{Fe} 3+/\left(\mathrm{Fe}^{3+}+\mathrm{Fe}^{2+}\right)=0.43-$ $0.48)$ (Table 1; Figures 4a to 4c).

Type I chromite is found in clinopyroxene-bearing massive, semi-massive and disseminated samples from Los Congos and Los Guanacos massifs, whereas Type II chromite is preserved exclusively in clinopyroxene-bearing disseminated samples from Los Congos, and Type III chromite occurs in clinopyroxene-free massive chromitites from Los Guanacos (Table 1).

The three varieties of chromite are made up by subhedral and less frequently anhedral crystals (from 0.2 to $1 \mathrm{~cm}$ across) with rounded shapes, and have a fracture network of variable density (Figure $3)$; these fractures are often filled with secondary silicates (i.e., antigorite and chlorite), and less frequently with carbonates (Figure 3c). No primary olivine was observed in the chromitites, whereas antigorite and chlorite forms the interstitial matrix between chromite grains (Figure 3). Clinopyroxene are also found intergranular to Type I and Type II chromites (Figures 3a and 3b). Small inclusions of these silicate minerals are scattered within chromite grains.

In situ LA-ICP-MS analyses of Type I chromite in massive chromitites from Los Congos and Los Guanacos show variable albeit similar contents of $\mathrm{Ga}$ (10.32-32.70 ppm), Ti (615-1354 ppm), Zn (1282-2853 ppm), and Mn (2890-8215 ppm), higher contents of Sc (1.5-10.07 ppm) and $\mathrm{Ni}$ (1012-2386 ppm), and lower contents of Co (287-370 ppm) and V (657-1007 ppm) than those in semi-massive chromitites from Los Guanacos 

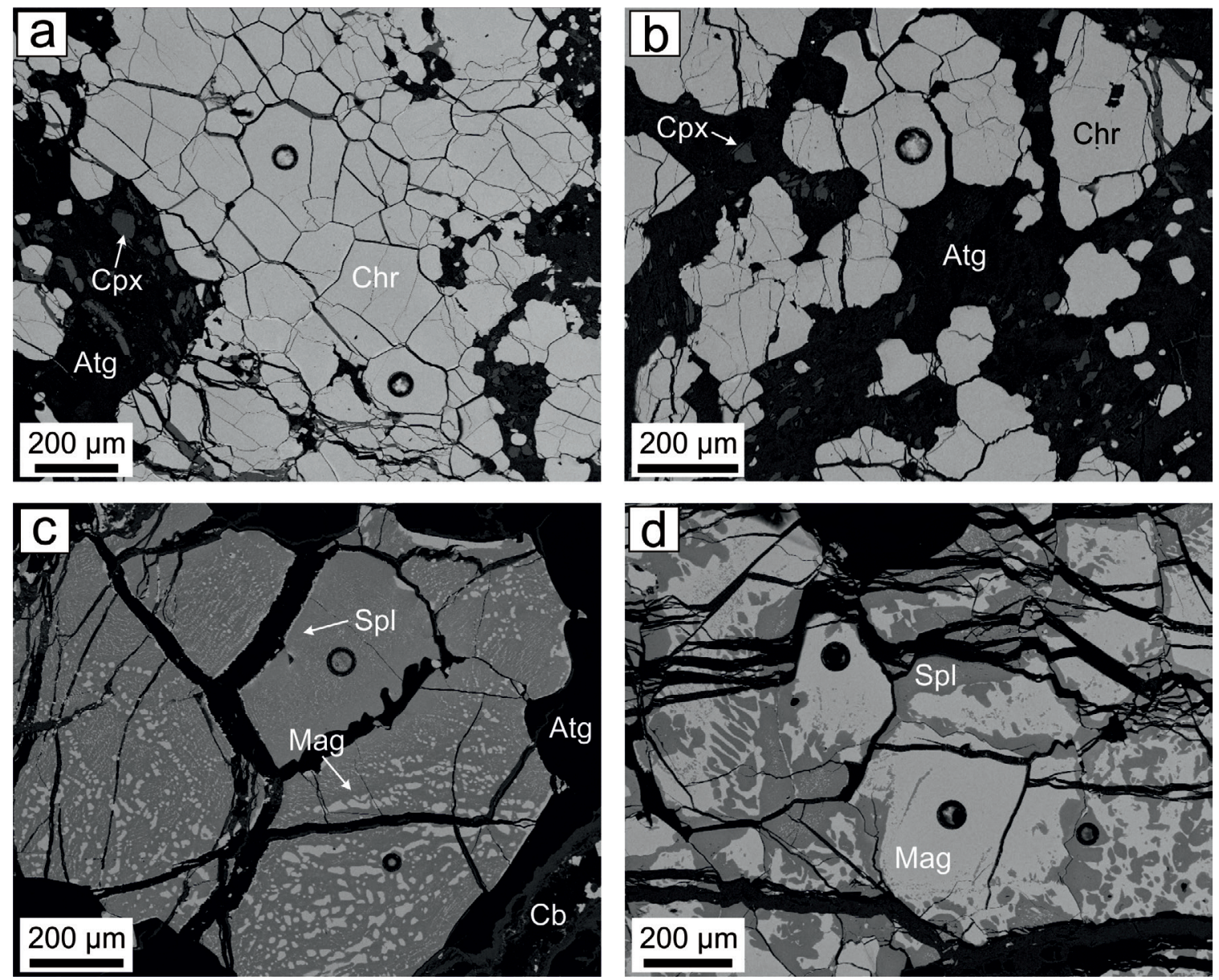

Figure 3 Backscattered-electron (BSE) images of the different textural varieties of chromites identified in Los Congos and Los Guanacos chromitite bodies. Type I chromite in massive (a) and semi-massive chromitites (b) with relics of clinopyroxene; Type II chromite from Los Congos (c) and Type III chromite from Los Guanacos (d). Abbreviations: Atg: antigorite, Cb: carbonates, Chr: chromite, Cpx: clinopyroxene, Mag: magnetite, Spl: spinel (Whitney and Evans, 2010).

$(\mathrm{Ga}=18.96-27.46 \mathrm{ppm}, \mathrm{Ti}=746-1449 \mathrm{ppm}, \mathrm{Zn}$ $=1974-2508 \mathrm{ppm}, \mathrm{Mn}=2540-3172 \mathrm{ppm}, \mathrm{Sc}=$ 0.33-1.23 ppm, $\mathrm{Ni}=634-851 \mathrm{ppm}, \mathrm{Co}=372-$ $397 \mathrm{ppm}, \mathrm{V}=1118-1255 \mathrm{ppm}$ ) (Figure 5a to 5b). Spinel-rich phase of Type III chromite in massive chromitites from Los Guanacos are enriched in Ga (26.95-30.13 ppm), Co (616-699 ppm) and Zn (5118-6024 ppm), but depleted in Sc (1.03-2.02 ppm), V (598-836 ppm), Ti (302-526 ppm), Mn (3244-4197 ppm) and $\mathrm{Ni}(1781-2877 \mathrm{ppm})$ than the magnetite-rich phase $(\mathrm{Ga}=9.42-14.88 \mathrm{ppm}$, $\mathrm{Co}_{\mathrm{o}}=280-407 \mathrm{ppm}, \mathrm{Zn}=846-1082 \mathrm{ppm}, \mathrm{Sc}=$ 2.19-4.67 ppm, $\mathrm{V}=830-1282 \mathrm{ppm}, \mathrm{Ti}=876-$ $1378 \mathrm{ppm}, \mathrm{Mn}=3097-5083 \mathrm{ppm}, \mathrm{Ni}=3700-$ $5812 \mathrm{ppm}$ ) (Figure 5c and 5d). In situ analyses of Type II chromite from Los Congos were excluded because the beam size of LA-ICP-MS ( 30-50 $\mu \mathrm{m})$ is larger than the size of the exsolved phases (see Figure 3c).

\subsection{SILICATE MINERALS}

Antigorite is present in Type I, Type II and Type III chromites (Table 1), but its composition varies in the different ultramafic massifs. Antigorite crystals in the chromitite bodies from Los Congos $(\mathrm{n}=$ 9) vary within the following ranges: 42.42-44.66 wt. $\% \mathrm{SiO}_{2}, 36.04-39.33$ wt. $\% \mathrm{MgO}, 3.01-3.99$ wt. $\% \mathrm{Al}_{2} \mathrm{O}_{3}, 1.48-3.19$ wt. $\% \mathrm{FeO}$, and 0.68-1.39 wt. $\% \mathrm{Cr}_{2} \mathrm{O}_{3}$. Antigorite from Los Guanacos $(\mathrm{n}=$ 12) has relatively higher $\mathrm{MgO}$ (37.24-41.12 wt. \%) and $\mathrm{FeO}$ (1.77-3.30 wt.\%), but relatively lower 
Table 1. Characterization of the chromitite samples investigated in this study.

\begin{tabular}{|c|c|c|c|c|c|c|c|c|}
\hline \multirow{2}{*}{$\begin{array}{l}\text { Chromite } \\
\text { variety }\end{array}$} & \multirow{2}{*}{ Locality } & \multirow{2}{*}{ Sample } & \multicolumn{2}{|c|}{ Chromitite body } & \multirow{2}{*}{$\begin{array}{l}\text { Chromite } \\
\text { phase }\end{array}$} & \multicolumn{3}{|c|}{ Chemical variations } \\
\hline & & & Texture & Silicate matrix & & $\mathrm{Cr} \#_{\text {at }}$ & $\mathbf{M g} \#_{\text {at }}$ & $\mathrm{Fe}^{3+} /\left(\mathrm{Fe}^{3+}+\mathrm{Fe}^{3+}\right)$ \\
\hline \multirow{4}{*}{ Type I } & Los Congos & M-25 & \multirow{2}{*}{ Massive } & $\begin{array}{l}\text { Atg (10 vol\%) } \\
\text { Cpx (10 vol\%) }\end{array}$ & \multirow{4}{*}{ Chromite-rich } & $0.47-0.58$ & $0.61-0.68$ & $0.44-0.54$ \\
\hline & \multirow{3}{*}{ Los Guanacos } & M-17 & & $\begin{array}{l}\text { Atg (15 vol\%) } \\
\text { Cpx (3 vol\%) } \\
\text { Clc (2 vol\%) }\end{array}$ & & $0.62-0.72$ & $0.52-0.57$ & $0.44-0.48$ \\
\hline & & 3317 & Semi-massive & $\begin{array}{l}\text { Atg (35 vol\%) } \\
\text { Cpx, (4 vol } \%) \\
\text { Clc (4 vol } \%)\end{array}$ & & $0.60-0.73$ & $0.48-0.55$ & $0.24-0.27$ \\
\hline & & $2260 a$ & Disseminated & $\begin{array}{l}\text { Atg }(55 \text { vol } \%) \\
\text { Cpx (7 vol\%) } \\
\text { Clc (5 vol } \%)\end{array}$ & & $0.55-0.63$ & $0.42-0.52$ & $0.43-0.48$ \\
\hline \multirow{2}{*}{ Tipe II } & \multirow{2}{*}{ Los Congos } & \multirow{2}{*}{ M-27 } & \multirow{2}{*}{ Disseminated } & \multirow{2}{*}{$\begin{array}{l}\operatorname{Atg}(50-70 \text { vol } \%) \\
\text { Cpx, }(4 \text { vol } \%)\end{array}$} & Spinel-rich & $0.50-0.54$ & $0.56-0.63$ & $0.43-0.52$ \\
\hline & & & & & Magnetite-rich & $0.85-0.87$ & $0.21-0.23$ & $0.62-0.63$ \\
\hline \multirow{3}{*}{ Type III } & \multirow{3}{*}{ Los Guanacos } & \multirow{3}{*}{2226} & \multirow{3}{*}{ Massive } & \multirow{3}{*}{$\operatorname{Atg}(<20$ vol $\%)$} & Spinel-rich & $0.41-0.43$ & $0.64-0.73$ & $0.40-0.54$ \\
\hline & & & & & Magnetite-rich & $0.76-0.79$ & $0.29-0.33$ & $0.62-0.64$ \\
\hline & & & & & Chromite-rich $^{(a)}$ & $0.54-0.59$ & $0.44-0.50$ & $0.60-0.61$ \\
\hline
\end{tabular}

Note: Mineral abbreviations after Whitney and Evans (2010).

(a) Composition calculated using the proportion of each phase in exsolved chromites according to Colás et al. (2016).

$\mathrm{SiO}_{2}\left(39.71-43.16\right.$ wt. \%), $\mathrm{Al}_{2} \mathrm{O}_{3}$ (up to 0.71 wt. \%), and $\mathrm{Cr}_{2} \mathrm{O}_{3}(0.03-0.26$ wt. \%) than those from Los Congos (Appendix 2).

Chlorite $(\mathrm{n}=8)$ associated with Type I chromite in chromitites from Los Guanacos (Table 1) have narrowly variable $\mathrm{SiO}_{2}(29.01-31.87$ wt. $\%), \mathrm{Al}_{2} \mathrm{O}_{3}$ (17.45-18.36 wt.\%), $\mathrm{MgO}(32.78-34.27$ wt. $\%)$, and $\mathrm{FeO}(1.83-2.63$ wt.\%) (Appendix 2). All the analysed grains contain significant amounts of $\mathrm{Cr}_{2} \mathrm{O}_{3}(1.94-3.95$ wt. \%), but their low $\mathrm{Fe} /(\mathrm{Fe}+\mathrm{Mg})$ ratios (up to 0.04) overlap the compositional field of clinochlore defined by Hey (1954) (Appendix 2).

Clinopyroxene $(\mathrm{n}=26)$ identified in Type I and Type II chromites (Table 1) has a Mg-rich augite composition $\left(\mathrm{Wo}_{28-29} \mathrm{En}_{67-69} \mathrm{Fs}_{3-5}\right)$ (Appendix 2), but its composition varies in different types of chromite. Clinopyroxene grains which are associated with Type I chromite in chromitites from Los Congos and Los Guanacos (Table 1) show similar $\mathrm{Mg} \#$ (0.94-0.96), $\mathrm{SiO}_{2}$ (55.29-57.19 wt.\%), $\mathrm{Al}_{2} \mathrm{O}_{3}$ (2.19-4.06 wt.\%) and $\mathrm{CaO}$ (12.96-13.89 wt.\%), with relatively higher $\mathrm{Na}_{2} \mathrm{O}(0.16-0.36$ wt. $\%)$ and $\mathrm{Cr}_{2} \mathrm{O}_{3}$ (0.55-1.09 wt.\%), and lower $\mathrm{TiO}_{2}$ (0.100.25 wt. $\%)$ and $\mathrm{MnO}(0.02-0.13$ wt. $\%)$ than those from Type II chromites in Los Congos $(\mathrm{Mg} \#=$ 0.93-0.94, $\mathrm{SiO}_{2}=54.53-56.55$ wt. $\%, \mathrm{Al}_{2} \mathrm{O}_{3}=$ 3.50-4.96 wt. $\%, \mathrm{CaO}=13.22-13.38$ wt. $\%, \mathrm{Na}_{2} \mathrm{O}$ $=0.13-0.26$ wt. $\%, \mathrm{Cr}_{2} \mathrm{O}_{3}=0.43-0.72$ wt. $\%, \mathrm{TiO}_{2}$ $=0.22-0.33$ wt. $\%$, and $\mathrm{MnO}=0.13-0.15$ wt. $\%$ ) (Appendix 2).

\section{Discussion}

\subsection{RETROGRADE METAMORPHIC FINGERPRINTS IN GHROMITITES}

Type III chromite prior to exsolution $(\mathrm{Mg} \#=$ 0.44-0.50) and Type I chromites in disseminated chromitites have lower Mg\# (0.42-0.52) with respect to those in massive chromitites $(\mathrm{Mg} \#=$ 0.61-0.68), expanding between and parallel to the $\mathrm{Fo}_{85}$ and $\mathrm{Fo}_{93}$ contours (Table 1; Figure 4). This 

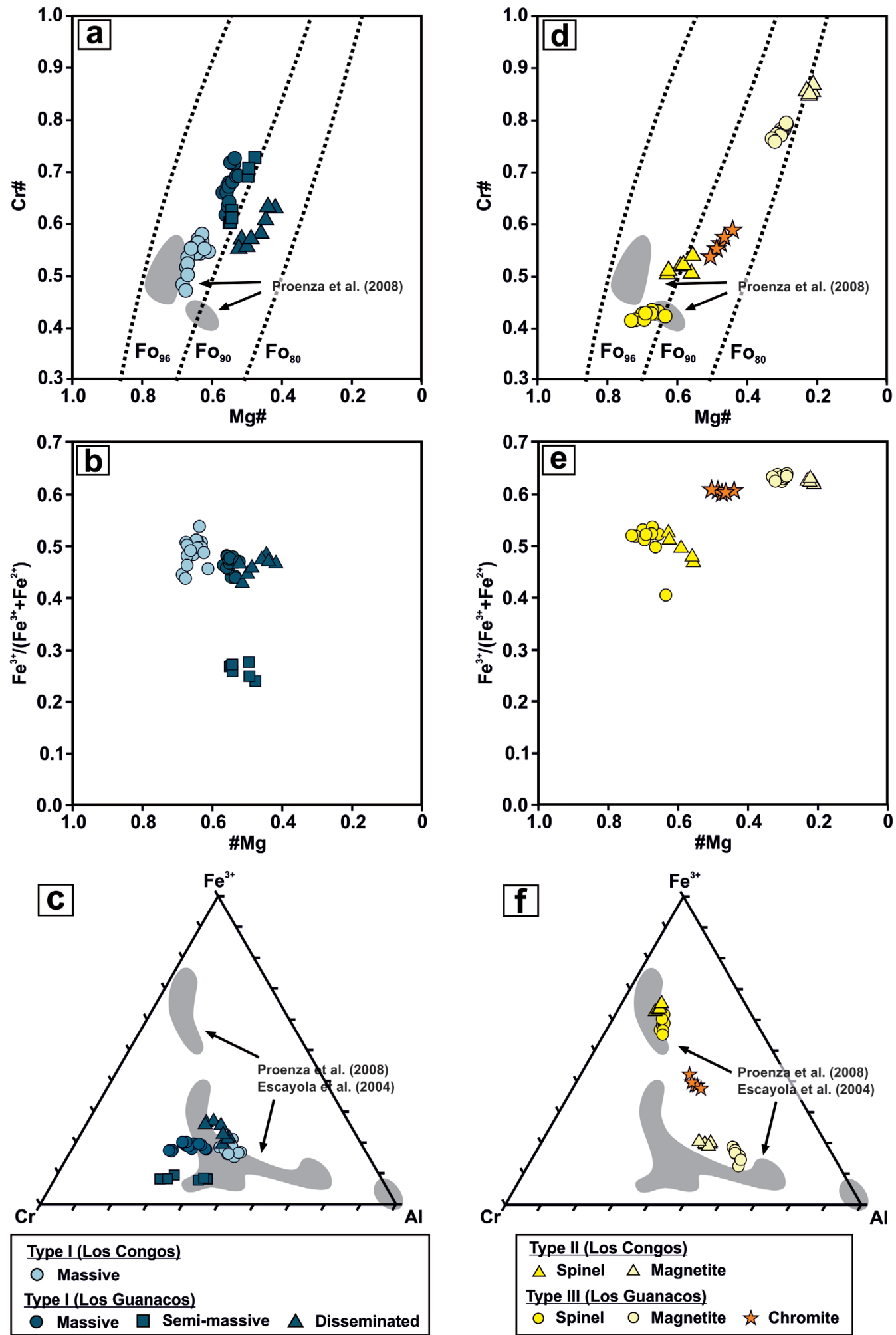

Figure 4 Compositional variations of chromite grains in the studied chromitites from Los Congos and Los Guanacos in terms of $\mathrm{Mg} \#\left[\mathrm{Mg} /\left(\mathrm{Mg}+\mathrm{Fe}^{2+}\right)\right.$ atomic ratio] versus $\mathrm{Cr} \#\left[\mathrm{Cr} /(\mathrm{Cr}+\mathrm{Al})\right.$ atomic ratio] $(\mathrm{a}$ and $\mathrm{d})$ and $\mathrm{Fe}^{3+} /\left(\mathrm{Fe}^{2+}+\mathrm{Fe}^{3+}\right)$ ratio $\left(\mathrm{b}\right.$ and e), and $\mathrm{Al}-\mathrm{Cr}-\mathrm{Fe}{ }^{3+}$ compositions ( $c$ and $f$ ). Legend provided as inset in the figure. Dashed lines in ( $a$ and $d$ ) denote the composition of olivine in equilibrium with chromite at a nominal temperature of $1,200{ }^{\circ} \mathrm{C}$ (Dick and Bullen, 1984). Shaded fields in plots are the composition of chromite from Los Congos and Los Guanacos chromitites reported by Escayola et al. (2004) and Proenza et al. (2008). 

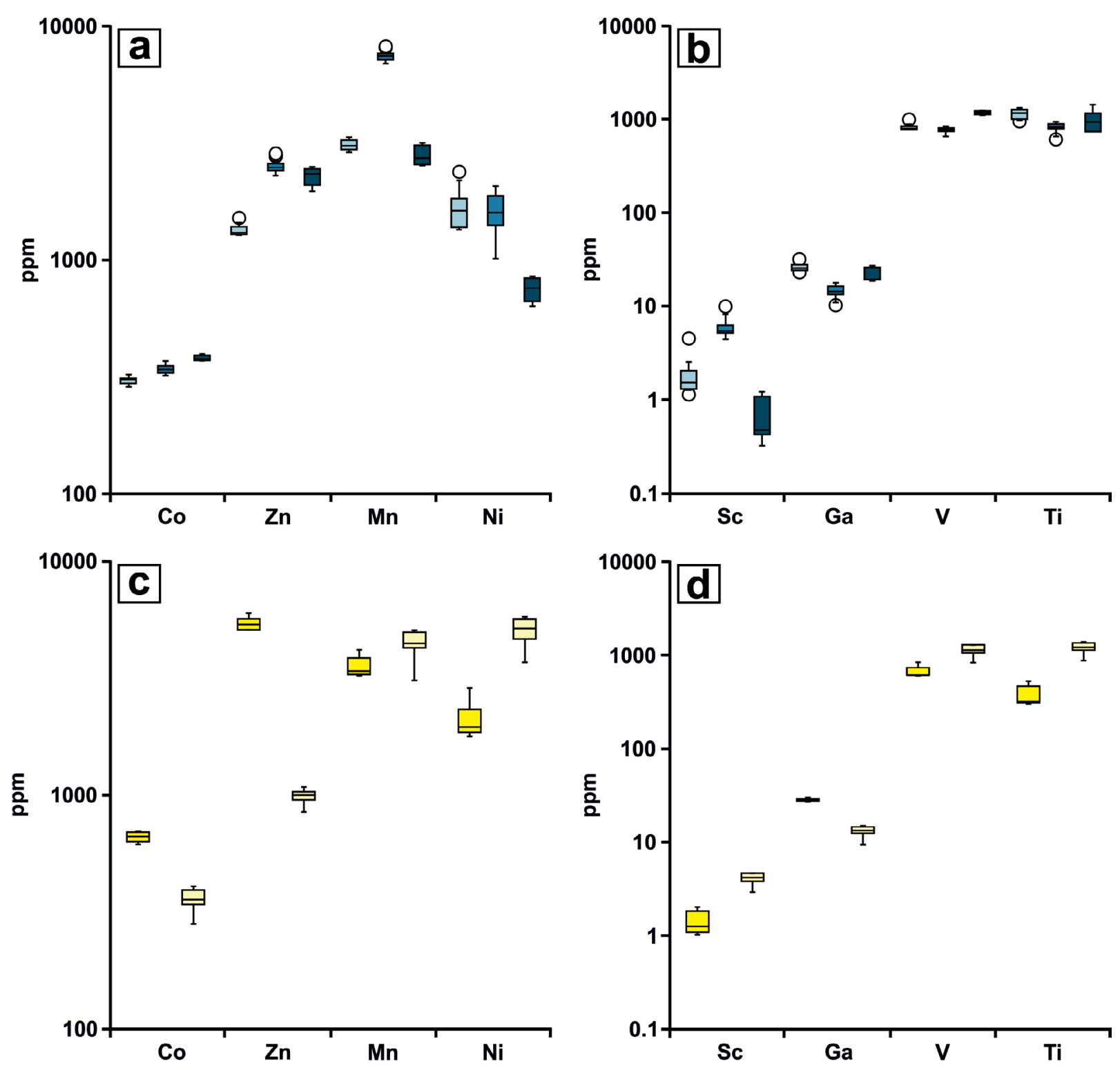

$$
\begin{array}{lll}
\text { Type I (Los Congos) } & \text { Type I (Los Guanacos) } & \text { Type III (Los Guanacos) } \\
\square \text { Massive } & \square \text { Massive } \square \text { Semi-massive } & \square \text { Spinel } \square \text { Magnetite }
\end{array}
$$

Figure 5 Box chart diagrams illustrating the content of divalent ( $a$ and c), trivalent and tetravalent (b and d) minor and trace elements in the different textural varieties of chromite identified in Los Congos and Los Guanacos chromitites. Elements arranged according to Colás et al. (2019). 
trend is similar to that described in non-metamorphosed chromitites from ophiolites elsewhere, where accessory chromites hosted in olivine are enriched in $\mathrm{FeO}$ and the olivine interstitial to chromite in chromitite bodies is enriched in $\mathrm{MgO}$ (Leblanc and Nicolas, 1992). It could be attributed to the $\mathrm{Mg}^{2+} \leftrightarrow \mathrm{Fe}^{2+}$ exchange between chromite and olivine at high temperatures (i.e., 1000-900 ${ }^{\circ} \mathrm{C}$ ) during postmagmatic cooling (Irvine, 1967). Thus, a decrease of $\mathrm{Mg \#}$ at relatively constant Cr\# should be expected in the chromite grains from chromitites with lower chromite/silicate ratios. However, this hypothesis is not valid for Type I and Type III chromites prior to exsolution from Los Congos and Los Guanacos because the decrease of $\mathrm{Mg} \#$ is associated with an increase of Cr\# (from 0.47 to 0.73 in Type I chromite and from 0.54 to 0.59 in Type III chromite prior to exsolution) (Table 1; Figure 4a and 4c).

The trend of $\mathrm{Cr}_{2} \mathrm{O}_{3}$ and $\mathrm{FeO}$ gain coupled with the $\mathrm{MgO}$ and $\mathrm{Al}_{2} \mathrm{O}_{3}$ loss showed in Type I and Type III chromites prior to exsolution (Table 1; Figure $4 \mathrm{a}$ and $4 \mathrm{~d}$ ) is similar to those reported in chromitites from metamorphosed ophiolites elsewhere (e.g., Gervilla et al., 2012; Prabhakar and Bhattacharya 2013; Ahmed and Surour, 2016; González-Jiménez et al., 2016; Kapsiotis et al., 2018; Yu et al., 2019). These chemical variations are usually characteristic of $\mathrm{Fe}^{2+}$-rich porous chromite rims or grains formed by the reaction of magmatic chromite with olivine and/or pyroxene during the retrograde hydrous metamorphism, in presence of $\mathrm{SiO}_{2}$-rich and $\mathrm{MgO}$-poor fluids derived from the host ultramafic rocks (e.g., Bach et al., 2006; Frost et al., 2013; Majumdar et al., 2016; Colás et al., 2017). This hydration process produced the mass loss of primary chromite and the preferential partitioning of $\mathrm{MgO}$ and $\mathrm{Al}_{2} \mathrm{O}_{3}$ towards chlorite that crystallized inside the pores of $\mathrm{Fe}^{2+}$-rich porous chromite, and also the formation of antigorite in the matrix (e.g., Gervilla et al., 2012; Barra et al., 2014; González-Jiménez et al., 2016; Colás et al., 2019). Interestingly, Type I chromite in disseminated chromitites is significantly more enriched in Co and $\mathrm{V}$ and depleted in $\mathrm{Ni}$ than chromite in mas- sive chromitites (Figure 5a and 5b). This suggests that a greater element mobility could take place as a result of highly effectiveness in chromite grains with lowest chromite/silicate and high fluid/rock ratios (i.e. semi-massive chromites) (Loferski, 1986; Candia and Gaspar, 1997; Proenza et al. 1999; Merlini et al. 2009; Barra et al. 2014; Colás et al. 2017).

In contrast, the high contents in $\mathrm{Fe}_{2} \mathrm{O}_{3}$ in the Type I and Type III chromites prior to exsolution from Los Congos and Los Guanacos $\mathrm{Fe}^{3+} /$ $\left(\mathrm{Fe}^{3+}+\mathrm{Fe}^{2+}\right)$ from 0.24 to 0.54 in Type I, and from 0.60 to 0.61 in Type III chromite prior to exsolution] (Table 1; Figure 4) are usually associated with the modification of $\mathrm{Fe}^{2+}$-rich porous chromite to $\mathrm{Fe}^{3+}$-rich non-porous chromite during the retrograde hydrous metamorphism. This process is a consequence of the exhaustion of olivine and pyroxene from the chromitites and host ultramafic rocks, and the progressive increase of $\mathrm{fO}_{2}$ and $\mathrm{SiO}_{2}$ in the fluid (i.e., more oxidizing conditions), which promoted the oxidation of $\mathrm{Fe}^{2+}$ and the subsequent increase of $\mathrm{Fe}^{3+}$ in the system (e.g., Alt and Shanks, 1998; Bach et al., 2004, 2006; Alt et al., 2007). These fluids would have reacted with $\mathrm{Fe}^{2+}$-rich porous chromite through the pre-existing pore network, thus dissolving chlorite and precipitating magnetite in the remaining porosity (e.g., Satsukawa et al., 2015; Colás et al., 2019; Gervilla et al., 2019). The diffusion of $\mathrm{Fe}^{3+}$ and $\mathrm{Fe}^{2+}$ through pores resulted in the development of $\mathrm{Fe}^{3+}$-rich non-porous chromite, obliterating the igneous chemical signature of the pre-existing chromite (e.g., Gervilla et al., 2012; Barra et al., 2014; Colás et al., 2019; Yu et al, 2019). In this context, the lowest $\mathrm{Fe}^{3+} /\left(\mathrm{Fe}^{3+}+\mathrm{Fe}^{2+}\right)$ ratios $(0.24-$ 0.27) showed by Type I chromite in semi-massive chromitites and the highest $\mathrm{Fe}^{3+} /\left(\mathrm{Fe}^{3+}+\mathrm{Fe}^{2+}\right)$ ratios (0.60-0.61) displayed by Type III chromite prior to exsolution (Table 1; Figure 4) suggest an uneven efficiency of the alteration process, which could be significantly affected by the presence of secondary permeability in the chromitites and/or by variable fluid/rock ratios (e.g., Loferski, 1986; Candia and Gaspar, 1997; Colás et al., 2017). 


\subsection{PROGRADE METAMORPHIC FINGERPRINTS IN CHROMITITES}

The absence of $\mathrm{Fe}^{2+}$-rich porous chromite and/ or $\mathrm{Fe}^{3+}$-rich non-porous chromite rims in Type I chromites and the presence of exsolved textures in Type III chromites (Figure 3) suggest a change in the metamorphic conditions. Type I and Type III chromites prior to exsolution have albeit similar $\mathrm{Mg} \#$ (from 0.42 to 0.68 in Type I, and from 0.44 to 0.50 in Type III chromite prior to exsolution) and Cr\# (from 0.47 to 0.73 in Type I, and from 0.54 to 0.59 in Type III chromite prior to exsolution), but higher $\left(\mathrm{Fe}^{3+} /\left(\mathrm{Fe}^{3+}+\mathrm{Fe}^{2+}\right)\right.$ ratios (from 0.24 to 0.54 in Type I, and from 0.60 to 0.61 in Type III chromite prior to exsolution) than primary chromite reported in Los Guanacos by Proenza et al. (2008) $\left(\mathrm{Cr} \#=0.48-0.56, \mathrm{Mg} \#=0.61-0.75\right.$, and $\mathrm{Fe}^{3+} /$ $\left(\mathrm{Fe}^{3+}+\mathrm{Fe}^{2+}\right)=0.30-0.36$; Figure 4). According to González-Jiménez et al. (2015), the dehydration of previously hydrated chromitite bodies during the thermal prograde metamorphism may produce the reaction of $\mathrm{Fe}^{2+}$-rich porous and/or $\mathrm{Fe}^{3+}$-rich non-porous chromite with antigorite and chlorite from the pores and/or matrix. This process formed an optically homogeneous chromite with a composition close to igneous chromite -i.e., a chromite with lower $\mathrm{Cr}_{2} \mathrm{O}_{3}$ but higher $\mathrm{MgO}, \mathrm{Al}_{2} \mathrm{O}_{3}$ and $\mathrm{Fe}_{2} \mathrm{O}_{3}$ than that formed by the retrograde hydrous metamorphism- in equilibrium with $\mathrm{Mg}$-rich olivine and/or pyroxene (e.g., Padrón-Navarta et al. 2010, 2013).

It is worth noting that Type I chromites from Los Congos and Los Guanacos shows patterns of minor and trace elements with lower $\mathrm{Ga}$ and higher $\mathrm{Co}, \mathrm{Zn}$ and $\mathrm{Mn}$ than those chromites from non-metamorphosed ophiolitic chromitites (i.e., chromites form back-arc and oceanic suprasubduction zone (SSZ) mantle; Figure 6a to 6c). This suggests that the distribution of minor and trace elements in Type I chromite was disturbed significantly by the formation of $\mathrm{Fe}^{3+}$-rich non-porous chromite during retrograde hydrous metamorphism, and the subsequent re-equilibrium between those hydrated chromites and silicates during the prograde metamorphism. This is consistent with the fact that the enrichment of $\mathrm{Go}, \mathrm{Zn}$ and $\mathrm{Mn}$ coupled with the depletion of $\mathrm{Ga}$ in chromite was interpreted as a result of the formation of chlorite and antigorite by the hydration of chromite during the retrograde metamorphism (Colás et al., 2014). This hypothesis is also supported by (i) the absence of $\mathrm{Fe}^{2+}$-rich porous and/or $\mathrm{Fe}^{3+}$-rich non-porous chromite grains and/or rims in Type I chromites, and (ii) with the fact that these chromite grains have albeit similar distribution of minor and trace elements than $\mathrm{Fe}^{3+}$-rich non-porous chromite in metamorphosed ophiolitic chromitites from the Eastern Rhodopes in Bulgaria (Figure 6d; Colás et al., 2014; González-Jiménez et al., 2015, 2018).

Additionally, Type I chromite in massive chromitites exhibits similar Ga, Ti, Zn, and Mn, higher $\mathrm{Sc}$ and $\mathrm{Ni}$, and lower $\mathrm{Co}$ and $\mathrm{V}$ than that chromite in semi-massive chromitites (Table 1; Figure $5 \mathrm{a}$ and $5 \mathrm{~b})$. This is consistent with the fact (i) the dehydration of previously hydrated chromitites forms Mg-rich olivine and/or pyroxene with lower $\mathrm{Co}$ and higher $\mathrm{Ni}$ than Type I chromite (e.g., Zhang et al., 2018; Su et al., 2019), and (ii) the lowest contents of $\mathrm{Sc}$ and $\mathrm{Fe}_{2} \mathrm{O}_{3}\left[\mathrm{Fe}^{3+} /\left(\mathrm{Fe}^{3+}+\mathrm{Fe}^{2+}\right)\right.$ $=0.24-0.27$ (Table 1; Figure $4 \mathrm{~b}$ and $4 \mathrm{c}$ ) showed by Type I chromite in semi-massive chromitites is due to the preference of $\mathrm{Sc}$ for $\mathrm{Fe}^{3+}$-rich chromites (Wijbrans et al., 2015). Hence, these observations allow us to suggest that the major, minor and trace element composition of Type I and Type III chromites prior to exsolution from Los Congos and Los Guanacos (Figure 4a to 4f) was likely modified by the hydration of primary chromite during the retrograde hydrous metamorphism, and their subsequent dehydration during the prograde metamorphism.

\subsection{TEMPERATURE GONDITIONS OF GHROMITE ALTERATION}

Recent studies conducted by González-Jiménez et al. (2015, 2016) and Colás et al. (2017) reproduced the phase relations and temperature conditions of the alteration of chromite during the retrograde 

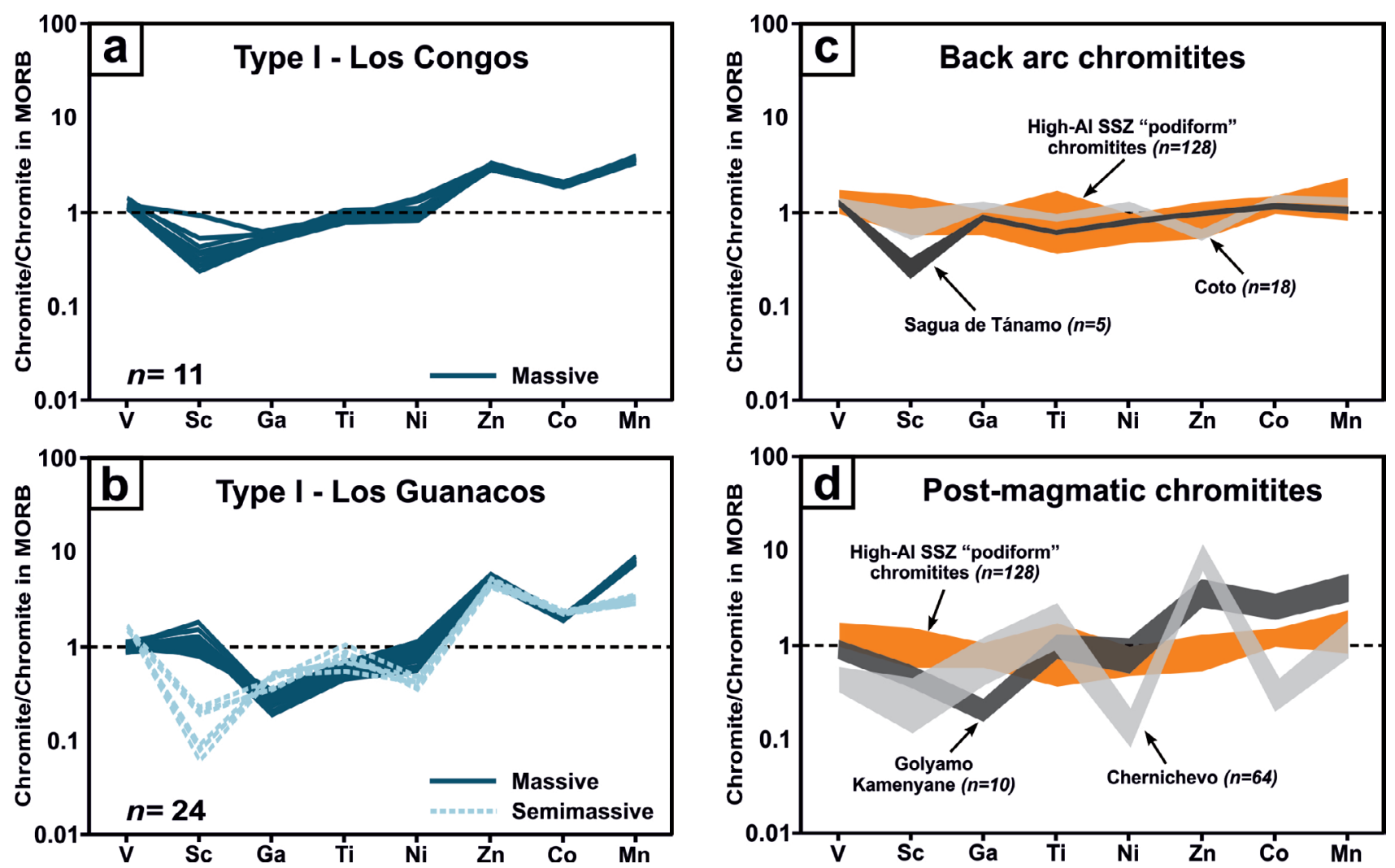

Figure 6 MORB-normalized minor and trace element distribution in Type I chromite grains from Los Congos and Los Guanacos chromitites ( $a$ and $b$ ) compared with high-Al non-metamorphosed chromitites (c) and with metamorphosed chromitites (d). MORB normalizing values are from Pagé and Barnes (2009). Data sources for high-Al chromites from suprasubduction zone (SSZ) mantlehosted podiform chromitites: Sartohay, China (Zhou et al., 2014); Islahiya, Doğanşehir (Akmaz et al., 2014) and Antalyalsparta (Uysal et al., 2016), Turkey; Mercedita (Colás et al., 2014) and Mayarí (Zhou et al., 2014), Cuba. Data source for back arc chromitites is from Coto, Philippines (Yao, 1999), and from Sagua de Tánamo, Cuba (González-Jiménez et al., 2015); and that of from metamorphic chromitites is from Golyamo Kamenyane (Colás et al, 2014) and Chernichevo (González-Jiménez et al. 2018), Bulgaria.

hydrous metamorphism in the system $\mathrm{Cr}_{2} \mathrm{O}_{3}-$ $\mathrm{MgO}-\mathrm{FeO}-\mathrm{Al}_{2} \mathrm{O}_{3}-\mathrm{SiO}_{2}-\mathrm{H}_{2} \mathrm{O} \quad$ (CrMFASH). However, this thermodynamic approach has limitations to model $\mathrm{Fe}^{3+}$-rich non-porous chromite as Type I, Type II and Type III chromites prior to exsolution from Los Congos and Los Guanacos because the solution model used for Cr-spinel does not include a calibration for the magnetite $\left(\mathrm{Fe}_{3} \mathrm{O}_{4}\right)$ end-member with an inverse spinel structure. Recent refinements of this thermodynamic modelling (González-Jiménez et al., 2018; Colás et al., 2019) now consider that the $\mathrm{Fe}_{2} \mathrm{O}_{3}$ content in $\mathrm{Fe}^{3+}$-rich non-porous chromite can be modelled as a magnetite component in the $\mathrm{FeO}-\mathrm{Fe}_{2} \mathrm{O}_{3}-\mathrm{MgO}-$ $\mathrm{Al}_{2} \mathrm{O}_{3}-\mathrm{SiO}_{2}-\mathrm{H}_{2} \mathrm{O}$ (FMASH) system, thus allowing a better constrain the temperature of formation of
$\mathrm{Fe}^{3+}$-rich non-porous chromite in chromitites from Los Congos and Los Guanacos.

Such an approach allowed us to construct a pseudosection for Type I chromite, contoured for $\mathrm{Cr} \#$ and $\mathrm{Mg} \#$, in the fluid-saturated $\mathrm{FeO}-\mathrm{Fe}_{2} \mathrm{O}_{3}-$ $\mathrm{Cr}_{2} \mathrm{O}_{3}-\mathrm{MgO}-\mathrm{Al}_{2} \mathrm{O}_{3}-\mathrm{CaO}-\mathrm{SiO}_{2}-\mathrm{H}_{2} \mathrm{O}$ (FCrMA$\mathrm{CaSH}$ ) system (Figure 7). In our computations, we have used an initial assemblage of chromitite bulk composition of semi-massive (57:35:04:04) molar mix of chromite, antigorite, clinopyroxene and chlorite (Table 1). The composition of chromite is the Type I chromite with the lowest $\mathrm{Fe}^{3+}$ / $\left(\mathrm{Fe}^{2+}+\mathrm{Fe}^{3+}\right)$ ratio $\left[\left(\mathrm{Mg}_{0.48} \mathrm{Fe}_{0.52}\right)\left(\mathrm{Cr}_{0.72} \mathrm{Al}_{0.28} \mathrm{Fe}_{0.08}\right) \mathrm{O}_{4}\right]$, and that of antigorite $\left[\left(\mathrm{Mg}_{0.48} \mathrm{Fe}_{0.52}\right)\left(\mathrm{Cr}_{0.73} \mathrm{Al}_{0.27} \mathrm{Fe}_{0.08}\right)\right.$ $\left.\mathrm{O}_{4}\right]$, clinopyroxene $\left[\left(\mathrm{Ca}_{0.5} \mathrm{Mg}_{1.44} \mathrm{Fe}_{0.06}\right) \mathrm{Si}_{2} \mathrm{O}_{6}\right]$ and chlorite $\left[\left(\mathrm{Mg}_{4.68} \mathrm{Fe}_{0.16}\right) \mathrm{Al}_{2} \mathrm{Si}_{3}(\mathrm{OH})_{8}\right]$ is the average 
composition of those silicates in semi-massive chromitites including Type I chromite (Figure 4a; Table 1; Appendices 1 and 2).

Our modelling shows that the maximum slope of $\mathrm{Cr} \#$ isopleths in chromite is located between ca. $800{ }^{\circ} \mathrm{C}$ at $20 \mathrm{kbar}$ and $500{ }^{\circ} \mathrm{C}$ at $1 \mathrm{kbar}$ (Figure $7 \mathrm{a}$ and $7 \mathrm{~b}$ ), predicting that under water-saturated conditions, primary chromite in semi-massive chromitites is not stable with olivine and pyroxene below $800{ }^{\circ} \mathrm{C}$. At these conditions, the stable assemblage is made up of chromite with higher $\mathrm{Cr} \#$ and lower $\mathrm{Mg} \#$ in equilibrium with chlorite, antigorite, brucite and magnetite (Figure 7a to 7c). The model also predicts that at the P-T conditions for ocean floor metamorphism (4 kbar and 300 ${ }^{\circ} \mathrm{C}$; Escayola et al., 1996, 2004) estimated for the host ultramafic rocks at Los Congos and Los Guanacos, chromite with $\mathrm{Cr} \#=1.00$ and $\mathrm{Mg} \#=0.25$ in semi-massive chromitite should form (green circle-1 in Figure 7b and 7c). Such modelled values are in accordance with the composition of $\mathrm{Fe}^{3+}$-rich non-porous chromite in metamorphosed chromitites at Tehuitzingo, Loma Baya in southern Mexico (Proenza et al., 2004; González-Jiménez et al., 2015, 2017; Colás et al., 2019; Farré-de-Pablo et al., 2019), Tapo in Peru (Colás et al., 2017), and La Cabaña ultramafic massifs in Chile (Barra et al., 2014; González-Jiménez et al., 2016; Plissart et al., 2019).

The occurrence of brucite along with chlorite and antigorite below $500{ }^{\circ} \mathrm{C}$ and $20 \mathrm{kbar}$ further support that ocean floor metamorphism took place under $\mathrm{SiO}_{2}$-poor water-saturated conditions (Colás et al., 2017). Furthermore, the predicted amount of magnetite is $<2.58 \mathrm{vol} . \%$, which can be explained as a result of olivine runoff and the oxidation of $\mathrm{Fe}^{2+}$ to $\mathrm{Fe}^{3+}$ in the solutions (e.g., Bach et al. 2004; Alt et al. 2007). This oxidizing fluids circulated through the network of pores in the $\mathrm{Fe}^{2+}$ rich porous chromite, thus dissolving chlorite and diffusing $\mathrm{Fe}^{2+}$ and $\mathrm{Fe}^{3+}$ into the chromite lattice and converts it to $\mathrm{Fe}^{3+}$-rich non-porous chromite (e.g., Gervilla et al., 2012; Barra et al., 2014; Colás et al., 2014, 2017, 2019; González-Jiménez et al., 2016, 2018).
However, Type I chromite in semi-massive chromitites have lower Cr\# (0.60-0.73) and higher $\mathrm{Mg} \#$ $(0.48-0.55)$ and $\mathrm{Fe}^{3+} /\left(\mathrm{Fe}^{3+}+\mathrm{Fe}^{3+}\right)(0.24-0.27)$ than modelled $\mathrm{Fe}^{3+}$-rich non-porous chromite (Figure 4 a to $4 \mathrm{c}$ ), which suggests a change in the metamorphic conditions (Figure 7a). According to Figure $7 \mathrm{a}$ to $7 \mathrm{c}$, an increase in $\mathrm{Al}_{2} \mathrm{O}_{3}, \mathrm{MgO}$ and $\mathrm{Fe}_{2} \mathrm{O}_{3}$ could be related to the breakdown of chlorite and antigorite if a prograde metamorphism affects the chromitite bodies. Hence, at the P-T conditions of the metamorphic peak $\left(10 \mathrm{kbar}\right.$ and $800^{\circ} \mathrm{C}$ as of Escayola et al., 1996, 2004) (green circle-2 in Figure 7) $\mathrm{Fe}^{3+}$-rich non-porous chromite reacts with chlorite+antigorite+brucite in the matrix. Such reaction of dehydration leads to the formation of homogeneous $\mathrm{Fe}^{3+}$-rich chromite with $\mathrm{Cr} \#=$ $0.65, \mathrm{Mg} \#=0.57$ (i.e., Type I chromite), olivine, orthopyroxene and clinopyroxene (Figure $7 \mathrm{a}$ to 7c). Clinopyroxene is very rare in non-metamorphosed ophiolitic chromitites, although diopside is found in Al-rich ophiolitic chromitites from the Mayarí-Baracoa Ophiolitic Belt in Cuba (Proenza et al., 1998, 1999; Pujol-Solà et al., 2018), which are spatially associated with gabbro dikes and sills. However, our thermodynamic model also predicts that olivine with $\mathrm{Fo}_{93}$ (Figure $7 \mathrm{~d}$ ) and $\mathrm{Mg}$-rich clinopyroxene (the predicted $\mathrm{Mg} \#$ is 0.97; Figure 7a) were in equilibrium with a chromite with the composition of Type I chromite in semi-massive chromitites (Figures $4 \mathrm{a}$ to $4 \mathrm{c}$ and 7 ).

Significantly, the presence of exsolved textures in Type II and Type III chromites indicate a late cooling from granulite facies metamorphism to lower P-T conditions (Figures 3c, 3d and 7a). Contrary to the petrographic observations, our thermodynamic model cannot predict the exsolution of homogeneous $\mathrm{Fe}^{3+}$-rich non-porous chromite to spinel-rich and magnetite-rich phases in Type II and Type III chromites. However, at the minimum temperature estimated for the exsolution of such chromites (ca. $600{ }^{\circ} \mathrm{C}$; Colás et al., 2016) and the lowest pressures recorded in the associated granulites (from $4 \pm 0.5$ to $6.2 \pm 1$ kbar; Otamendi et al., 1999, 2004, 2005; Rapela et al., 1998; Martino et al., 2010) (orange rectangle-3 in 
Figure 7), chromite with higher Cr\# (0.94-0.98) and lower $\mathrm{Mg \#} \mathrm{(0.36-0.38)} \mathrm{than} \mathrm{Type} \mathrm{I} \mathrm{chromite}$ (Figure $7 \mathrm{~b}$ and $7 \mathrm{c}$ ) is in equilibrium with olivine, clinopyroxene, chlorite and antophillyte (Figure 7a). The presence of antigorite in the studied chromitites (Figure 3) vs. the predicted occurrence of olivine, clinopyroxene and chlorite by means of thermodynamic modelling (Figure 7), suggests that a final hydration of silicates did not fully progress at amphibolite facies conditions. Further, anthophyllite is not present in the studied chromitite samples (Figure 3), but it was described in ultramafic host rocks to the chromitite bodies at Los Guanacos (Escayola et al., 1996, 2004). Such occurrence can be explained as a consequence of higher rates of reaction between the infiltrating fluids and silicates in chromitites than between these fluids and the host ultramafic rocks. Therefore, these observations suggest (i) Type I, Type II and Type III chromites experienced high-T metamorphism at granulite facies condition after the formation of $\mathrm{Fe}^{3+}$-rich non-porous chromite by the hydrous metamorphic reaction that generated $\mathrm{Fe}^{2+}$-rich porous chromite and magnetite above 650-800 ${ }^{\circ} \mathrm{C}$ (Figure 7a to $7 \mathrm{~d}$; Colás et al., 2019); and (ii) the ultimate mineral assemblage preserved in Type I chromite, as well as the exsolution of Type II and Type III chromites started once the ultramafic body already entered within the P-T field of amphibolite facies (Figure 7).

\subsection{FORMATION OF EXSOLVED GHROMITES IN GHROMITITES}

Colás et al. (2016) suggested that the variety of textures in Los Congos and Los Guanacos chromitites is mainly controlled by the $\mathrm{Cr}_{2} \mathrm{O}_{3}$ and $\mathrm{Fe}_{2} \mathrm{O}_{3}$ content in chromite (Table 1; Figure 4a to 4f). Under the assumption that Type II and Type III chromites had a similar composition prior to exsolution, such a process could be represented on an ideal phase diagram of chromite (Figure 8). In this diagram, the composition in major elements of Type I chromite and spinel-rich and magnetite-rich phases in Type II and Type III chromites may be represented by an hypothetical solvus on the $\quad\left(\mathrm{Mg}_{0.5} \mathrm{Fe}^{2+}{ }_{0.5}\right) \mathrm{Cr}_{2} \mathrm{O}_{4}-\mathrm{MgAl}_{2} \mathrm{O}_{4}-\left(\mathrm{Mg}_{0.5} \mathrm{Fe}_{0.5}^{2+}\right)$ $\mathrm{Fe}^{3+}{ }_{2} \mathrm{O}_{4}$ plane, included in the Cr-spinel prism (Figure 8a and 8b) (Tamura and Arai, 2004). As shown in Figure $8 \mathrm{~b}$ to $8 \mathrm{~d}$, the extension of the solvus is more restricted in chromites with high $\mathrm{Cr}_{2} \mathrm{O}_{3}$, than in those with low $\mathrm{Cr}_{2} \mathrm{O}_{3}$. Therefore, Type I chromite with higher $\mathrm{Cr}_{2} \mathrm{O}_{3}$ but lower $\mathrm{Fe}_{2} \mathrm{O}_{3}$ contents $\left(\mathrm{Cr} \#=0.47-0.73\right.$ and $\mathrm{Fe}^{3+} /\left(\mathrm{Fe}^{2}\right.$ $\left.\left.{ }^{+}+\mathrm{Fe}^{3+}\right)=0.24-0.54\right)$ than Type II and Type III chromites $\left(\mathrm{Cr} \#=0.54-0.59\right.$ and $\mathrm{Fe}^{3+} /\left(\mathrm{Fe}^{2+}+\mathrm{Fe}^{3+}\right)$ $=0.60-0.61)$ (Table 1; Figure 4a to $4 \mathrm{f})$, should be expected to plot out of the solvus at $>600{ }^{\circ} \mathrm{C}$, which is the blocking temperature calculated by Colás et al. (2016) -i.e., the minimum possible temperature for exsolution (Figure 8b-c). However, Type II and Type III chromites prior to exsolution (i.e., $800{ }^{\circ} \mathrm{C}$, the metamorphic peak conditions estimated by Escayola et al., 1996, 2004) would be found in the miscibility gap during the cooling from granulite to amphibolite facies, as recorded in the host granulites (Escayola et al., 1996, 2004; Rapela et al., 1998; Otamendi et al., 1999, 2004, 2005; Martino et al., 2010).

In Figure 8d is also shown that Type III chromite prior to exsolution has, in a binary system, an intermediate composition of $\mathrm{Fe}_{2} \mathrm{O}_{3}\left(\mathrm{Fe}^{3+} /\right.$ $\left(\mathrm{Fe}^{2+}+\mathrm{Fe}^{3+}\right)=0.60-0.61$; (Table 1 and Figure $4 \mathrm{~d}$ to $4 \mathrm{f}$ ), which lies inside the spinoid at the blocking temperature. Thus, the symplectitic texture in Type III chromite (Figure 3c) could be effectively formed by phase separation of spinel-rich and magnetite-rich phases into the spinoid, as a consequence of a continuous and slow exsolution process through time (e.g., Kingery et al., 1976; Tamura and Arai, 2004). This exsolution process also produced the enrichment in Co, Zn, Sc, and $\mathrm{Ga}$ in the spinel-rich phase and the enrichment in $\mathrm{Mn}, \mathrm{Ni}, \mathrm{V}$ and $\mathrm{Ti}$ in the magnetite-rich phase in Type III chromite (Figures 5a and 5b). We have assumed that the original composition of Type II chromite was analogue to Type III chromite prior to exsolution $(\mathrm{Mg} \#=0.44-0.50, \mathrm{Cr} \#=0.54-0.59$, and $\mathrm{Fe}^{3+} /\left(\mathrm{Fe}^{3+}+\mathrm{Fe}^{2+}=0.60-0.61\right.$; Figure $4 \mathrm{a}$ to $\left.4 \mathrm{f}\right)$. This implies that Type II chromite should also plot inside the spinoid at the blocking temperature (Figure 8d). However, the presence of a magne- 

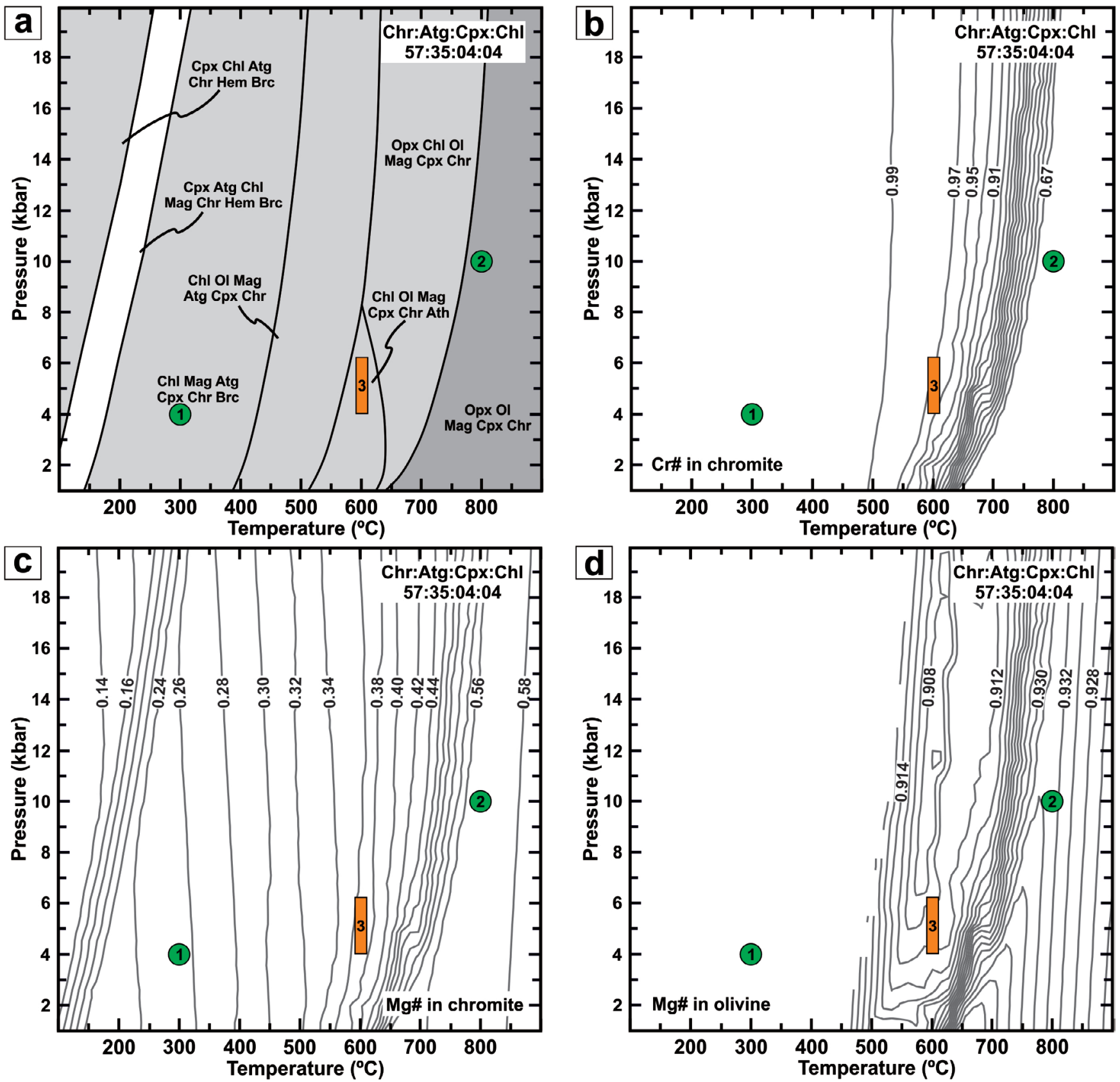

Figure 7 P-T pseudosection (a) and isopleths of $\mathrm{Cr} \#$ (b) and $\mathrm{Mg \#} \mathrm{(c)} \mathrm{in} \mathrm{chromite} \mathrm{and} \mathrm{Mg \#} \mathrm{(d)} \mathrm{in} \mathrm{olivine} \mathrm{calculated} \mathrm{for} \mathrm{a} \mathrm{semi-}$ massive chromitite (57:35:04:04 chromite:antigorite:clinopyroxene:chlorite molar proportions) in the fluid-saturated FCrMACaSH system. Green circles show the metamorphic conditions obtained by Escayola et al. (1996, 2004) in the ultramafic host rocks at Los Congos and Los Guanacos massifs. Orange rectangle show the temperature conditions estimated by Colás et al. (2016) for the exsolution of Type II and Type III chromites and the pressure conditions obtained by Rapela et al. (1998) and Martino et al. (2010) in the associated granulites. Abbreviations: Atg: antigorite, Ath: antophillyte, Chl: chlorite, Chr: chromite, Cpx: clinopyroxene, Hem: hematite, Mag: magnetite, Ol: olivine, Opx: orthopyroxene (Whitney and Evans, 2010). 
tite-rich phase in Type II chromite as irregular blebs or forming very fine lamellae within the spinel-rich phase (Figure 3d) indicates a discontinuous and relatively fast exsolution process.

The random distribution of magnetite-rich phase blebs along the rims or forming linear strings in Type II chromite grains (Figure 3d) suggests that such blebs are due to a slow cooling, probably at high temperatures (i.e., the metamorphic peak conditions at $800{ }^{\circ} \mathrm{C}$; Escayola et al., 1996, 2004) in which a relatively effective and fast intracrystalline diffusion of cations is favoured. However, the crystallographic control of the magnetite-rich phase lamellae implies that they could form at lower temperatures (i.e., the blocking temperature at ca. $600{ }^{\circ} \mathrm{C}$; Colás et al., 2016) because the intracrystalline diffusion of cations would be less efficient and slower, which would mean that exsolved phase could only concentrate along crystallographic planes. These two exsolution processes are analogue to those reported in chromites from the Chilas (Pakistan; Jan et al., 1992) and the Eastern Desert (Egypt; Ahmed et al., 2008) magmatic arcs, and from the Iwanai-dake peridotite complex (Japan; Tamura and Arai, 2004, 2005). Therefore, the different textures in Type I, Type II and Type III chromites in chromitite bodies from Los Congos and Los Guanacos are the consequence of: i) gradual variations in the $\mathrm{Cr}_{2} \mathrm{O}_{3}$ and $\mathrm{Fe}_{2} \mathrm{O}_{3}$ contents during the dehydration of previously hydrated chromitites by prograde metamorphism within the granulite facies, and ii) the cooling rates during the retrograde overprint within the amphibolite facies.
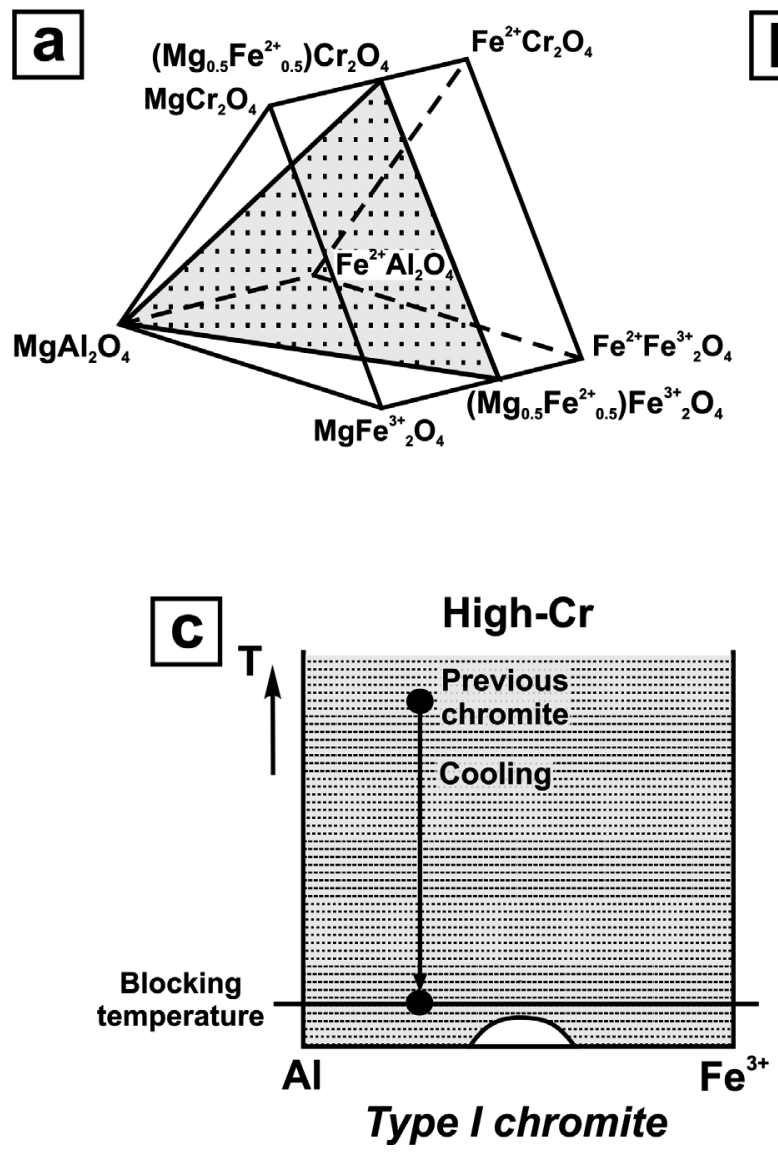
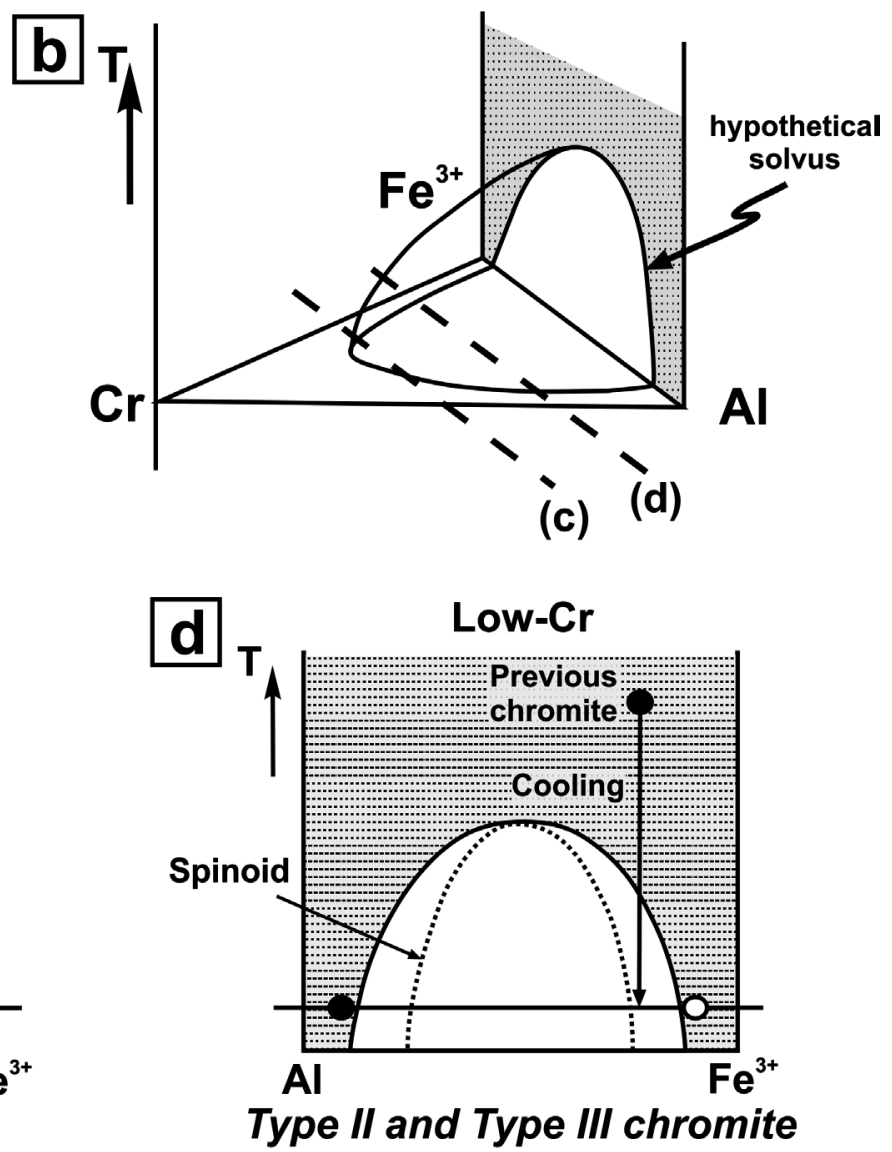

Figure 8 Schematic illustration for interpretation of the different textural varieties of chromite identified in Los Congos and Los Guanacos chromitites according to their composition. (a) Cr-spinel prism including the approximate plane for Type I, Type III and Type III chromite compositions. (b) Hypothetical solvus on the Cr-Al-Fe ${ }^{3+}$ plane calculated by Sack and Ghiorso (1991a). $\mathrm{Al}^{3+}-\mathrm{Fe}^{3+}$ planes that cut through the solvus of (b) at different high and low $\mathrm{Cr}^{3+}$ contents equivalent to Type I (c), Type II and Type III (d) chromite compositions (modified from Tamura and Arai, 2004). 


\section{Conclusions}

The observed textural varieties of chromite in Los Congos and Los Guanacos chromitites in the Eastern Pampean Ranges (north Argentina) were produced during a complex metamorphic evolution. The hydration of magmatic chromite in the course of the retrograde hydrous metamorphism resulted in the formation $\mathrm{Fe}^{3+}$-rich non-porous chromite, and the hydration of olivine and pyroxene to antigorite and chlorite in the matrix. A shift in metamorphic conditions to higher pressures and temperatures (i.e., prograde metamorphism) promoted the dehydration of $\mathrm{Fe}^{3+}$-rich non-porous chromite by its reaction with antigorite and chlorite. This process formed an optically homogeneous chromite with higher $\mathrm{Fe}_{2} \mathrm{O}_{3}, \mathrm{FeO}, \mathrm{Co}, \mathrm{Zn}$ and $\mathrm{Mn}$ but lower $\mathrm{Ga}$ than primary chromite by its equilibration with $\mathrm{Mg}$-rich olivine and pyroxene. The later-stage cooling was highlighted by the hydration of Mg-rich silicates in Type I chromite and by the exsolution of Type II and Type III chromites at different cooling rates. A continuous and slow cooling developed symplectitic textures in Type III chromite, thus mobilizing $\mathrm{Co}, \mathrm{Zn}, \mathrm{Sc}$, and $\mathrm{Ga}$ into the spinel-rich phase and $\mathrm{Mn}, \mathrm{Ni}, \mathrm{V}$ and $\mathrm{Ti}$ into the magnetite-rich phase. However, a discontinuous and relatively fast cooling produced the exsolution of irregular bleds and fine lamellae in Type II chromites. Thermodynamic calculations showed that the hydration of magmatic chromite to secondary $\mathrm{Fe}^{3+}$-rich non-porous chromite in equilibrium with chlorite, antigorite and brucite occurred below $500{ }^{\circ} \mathrm{C}$ and 20 kbar. Whereas, the dehydration of those minerals forms $\mathrm{Fe}^{3+}$-rich homogeneous chromite and $\mathrm{Mg}$-rich olivine and pyroxene in the matrix above $800{ }^{\circ} \mathrm{C}$ and $10 \mathrm{kbar}$. The subsequent hydration of silicates in Type I chromite and the exsolution of Type II and Type III chromites started at $\sim 600{ }^{\circ} \mathrm{C}$. Such $\mathrm{P}-\mathrm{T}$ framework is in agreement with the metamorphic pathway proposed for the evolution of the chromitite-bearing ultramafic rocks at Los Congos and Los Guanacos. This indicates that the prograde metamorphism within the granulite facies conditions exerted large compositional effects on the chromite grains that were previously hydrated during retrograde metamorphism. Therefore, the continent-continent collisional orogenies are the likeliest regional contexts to preserve the geochemical fingerprints of prograde metamorphism in the suprasubduction zone ophiolitic chromitites.

\section{Acknowledgments}

This research was supported by the research programs UNAM-PAPIIT (IA-101419) and Ciencia Básica of CONACYT (A1-S-14574). Thanks also to the Spanish research projects CGL201565824-P, CGL2014-55949-R, RTI2018-099157A-I00, PID2019-105625RB-C21 and the Ramón y Cajal Fellowship RYC-2015-17596 granted by the Spanish Ministerio de Ciencia, Innovación y Universidades and MINECO. The analytical data were obtained using instrumentation funded by DEST Systemic Infrastructure Grants, ARC LIEF, NCRIS/AuScope, industry partners and Macquarie University. We thank to Carlos Linares (Laboratorio de Universitario de Petrología, UNAM, Mexico) and Dr Augusto A. Rodriguez (Laboratorio de Petrografía y Microtermometría del Instituto de Geofísica, UNAM, Mexico) for their help with the EMPA analyses on silicates and with the backscattered electron (BSE) images, respectively. We would also like to thank Qing Xiong and Sisir Mondal for their formal reviews. This is a contribution 1489 from the ARC Centre of Excellence for Core to Crust Fluid Systems (http://www.ccfs. mq.edu.au) and 1382 in the GEMOC Key Centre (http://www.gemoc.mq.edu.au), and is related to IGCP-662.

\section{References}

Ahmed, A.H., Helmy, H.M., Arai, S., Yoshikawa, M., 2008, Magmatic unmixing in spinel from late Precambrian concentrically-zoned mafic-ultramafic intrusions, Eastern Desert, Egypt: Lithos, 104, 1, 85-98. https://doi. org/10.1016/j.lithos.2007.11.009 
Ahmed, A.H., Surour, A.A., 2016, Fluid-related modifications of Cr-spinel and olivine from ophiolitic peridotites by contact metamorphism of granitic intrusions in the Ablah area, Saudi Arabia: Journal of Asian Earth Sciences, 122, 58-79. https://doi. org/10.1016/j.jseaes.2016.03.010

Akmaz, R.M., Uysal, I., Saka, S., 2014, Compositional variations of chromite and solid inclusions in ophiolitic chromitites from the southeastern Turkey: Implications for chromitite genesis: Ore Geology Reviews, 58, 208-224. https://doi.org/10.1016/j. oregeorev.2013.11.007

Alt, J.C., Shanks, W.C., 1998, Sulfur in serpentinized oceanic peridotites: Serpentinization processes and microbial sulfate reduction: Journal of Geophysical Research: Solid Earth, 103, B5, 9917-9929.

Alt, J.C., Shanks, W.C., Bach, W., Paulick, H., Garrido, G.J., and Beaudoin, G., 2007, Hydrothermal alteration and microbial sulfate reduction in peridotite and gabbro exposed by detachment faulting at the Mid-Atlantic Ridge, $15^{\circ} 20^{\prime} \mathrm{N}$ (ODP Leg 209): A sulfur and oxygen isotope study: Geochemistry, Geophysics, Geosystems, 8, 8, - Q08002. https://doi.org/10.1029/2007GC001617

Arai, S., 1992, Chemistry of chromian spinel in volcanic rocks as a potential guide to magma chemistry: Mineralogical Magazine, 56, 383, 173-184. https://doi.org/10.1180/ minmag. 1992.056.383.04

Arai, S., Miura, M., 2016, Formation and modification of chromitites in the mantle: Lithos, 264, 277-295. https://doi. org/10.1016/j.lithos.2016.08.039

Bach, W., Garrido, G.J., Paulick, H., Harvey, J., Rosner, M., 2004, Seawater-peridotite interactions: First insights from ODP Leg 209, MAR $15^{\circ}$ N: Geochemistry, Geophysics, Geosystems, 5, 9, - Q09F26. https://doi. org/10.1029/2004gc000744

Bach, W., Paulick, H., Garrido, C.J., Ildefonse, B., Meurer, W.P., and Humphris, S.E., 2006, Unraveling the sequence of serpentinization reactions: petrography, mineral chemistry, and petrophysics of serpentinites from MAR $15^{\circ} \mathrm{N}$ (ODP Leg 209, Site 1274): Geophysical Research Letters, 33, 13, L13306. https:// doi.org/10.1029/2006gl025681

Barnes, S.J., Roeder, P.L., 2001, The range of spinel compositions in terrestrial mafic and ultramafic rocks: Journal of Petrology, 42, 12, 2279-2302. https://doi.org/10.1093/ petrology/42.12.2279

Barra, F., Gervilla, F., Hernández, E., Reich, M., Padrón-Navarta, J.A., González-Jiménez, J.M., 2014, Alteration patterns of chromian spinels from La Cabaña peridotite, southcentral Chile: Mineralogy and Petrology, 108, 6, 819-836. https://doi.org/10.1007/ s007 10-014-0335-5

Candia, M.A.F., Gaspar, J.C., 1997, Chromian spinels in metamorphosed ultramafic rocks from Mangabal I and II complexes, Goiás, Brazil: Mineralogy and Petrology, 60, 1, 2740. https://doi.org/10.1007/bf01 163133

Castroviejo, R., Pereira, E., Rodrigues, J.F., Acosta, J., 2009, Pre-andean serpentinite-chromite orebodies in the Eastern Cordillera of Central Peru, Tarma province, in Williams, P., ed., Smart science for exploration and mining: proceedings of the 10th Biennial SGA Meeting: Townsville, Australia, Economic Geology Research Unit James Cook University, 927-929.

Colás, V., González-Jiménez, J.M., Griffin, W.L., Fanlo, I., Gervilla, F., O’Reilly, S.Y., Pearson, N.J., Kerestedjian, T., Proenza, J.A., 2014, Fingerprints of metamorphism in chromite: new insights from minor and trace elements: Chemical Geology, 389, 137-152. https:// doi.org/10.1016/j.chemgeo.2014.10.001

Colás, V., Padrón-Navarta, J.A., GonzálezJiménez, J.M., Griffin, W.L., Fanlo, I., O'Reilly, S.Y., Gervilla, F., Proenza, J.A., Pearson, N.J., Escayola, M.P., 2016, Compositional effects on the solubility of minor and trace elements in oxide spinel minerals: Insights from crystal-crystal partition coefficients in chromite exsolution: 
American Mineralogist, 101, 6, 1360-1372. https://doi.org/10.2138/am-2016-561 1

Colás, V., Padrón-Navarta, J.A., GonzálezJiménez, J.M., Fanlo, I., López SánchezVizcaíno, V., Gervilla, F., Castroviejo, R., 2017, The role of silica in the hydrous metamorphism of chromite: Ore Geology Reviews, 90, 274-286. https://doi. org/10.1016/j.oregeorev.2017.02.025

Colás, V., González-Jiménez, J.M., Camprubí, A., Proenza, J.A., Griffin, W.L., Fanlo, I., O’Reilly, S.Y., Gervilla, F., González-Partida, E., 2019, A reappraisal of the metamorphic history of the Tehuitzingo chromitite, Puebla state, Mexico: International Geology Review, 61, 14, 1706-1727. https://doi.org/10.1080 /00206814.2018.1542633

Collo, G., Astini, R.A., Cawood, P.A., Buchan, C., Pimentel, M., 2009, U-Pb detrital zircon ages and $\mathrm{Sm}-\mathrm{Nd}$ isotopic features in low-grade metasedimentary rocks of the Famatina belt: implications for late Neoproterozoic-early Palaeozoic evolution of the proto-Andean margin of Gondwana: Journal of the Geological Society, 166, 2, 303-319. https:// doi.org/10.1144/0016-76492008-051

Connolly, J.A.D., 2009, The geodynamic equation of state: what and how: Geochemistry, Geophysics, Geosystems, 10, 10, Q10014. https://doi.org/10.1029/2009gc002540

Dick, H.J.B., Bullen, T., 1984, Chromian spinel as a petrogenetic indicator in abyssal and alpinetype peridotites and spatially associated lavas: Contributions to mineralogy and petrology, 86, 1, 54-76. https://doi.org/10.1007/ bf00373711t

Droop, G.T.R., 1987, A general equation for estimating $\mathrm{Fe}^{3+}$ concentrations in ferromagnesian silicates and oxides from microprobe analyses, using stoichiometric criteria: Mineralogical Magazine, 51, 361, 431-435. https://doi.org/10.1180/ minmag.1987.051.361.10

Escayola, M.P., Ramé, G., Kraemer, P.E., 1996, Caracterización y significado geotectónico de las fajas ultramáficas de las Sierras
Pampeanas de Córdoba: XIII Congreso Geológico Argentino y III Congreso de Exploración de Hidrocarburos., Actas, Tomo III, 421-438.

Escayola, M.P., Proenza, J.A., Schalamuk, A., Cábana, C., 2004, La secuencia ofiolítica de la faja ultramáfica de Sierras Pampeanas de Córdoba, Argentina. in Pereira, E., Castroviejo, R., Ortíz, F., eds., Complejos ofiolíticos en Iberoamérica: guías de prospección para metales preciosos: Madrid, España, Proyecto XIII.1-GYTED, 133-155.

Escayola, M.P., Pimentel, M.M., Armstrong, R., 2007, Neoproterozoic backarc basin: Sensitive high-resolution ion microprobe $\mathrm{U}-\mathrm{Pb}$ and $\mathrm{Sm}-\mathrm{Nd}$ isotopic evidence from the Eastern Pampean Ranges, Argentina: Geology, 35, 6, 495-498. https://doi. $\mathrm{org} / 10.1130 / \mathrm{g} 23549 \mathrm{a} .1$

Farré-de-Pablo, J., Proenza, J.A., GonzálezJiménez, J.M., Garcia-Casco, A., Colás, V., Roqué-Rossell, J., Camprubí, A., SánchezNavas, A., 2019, A shallow origin for diamonds in ophiolitic chromitites: Geology, 47, 1, 75-78. https://doi.org/10.1130/ g45640.1

Frost, B.R., Evans, K.A., Swapp, S.M., Beard, J.S., and Mothersole, F.E., 2013, The process of serpentinization in dunite from New Caledonia: Lithos, 178, 24-39. https://doi. org/10.1016/j.lithos.2013.02.002

Gervilla, F., Padrón-Navarta, J.A., Kerestedjian, T., Sergeeva, I., González-Jiménez, J.M., 2012, Formation of ferrian chromite in podiform chromitites from the Golyamo Kamenyane serpentinite, Eastern Rhodopes, SE Bulgaria: a two-stage process: Contributions to Mineralogy and Petrology, 164, 4, 643-657. https://doi.org/10.1007/ s00410-012-0763-3

Gervilla, F., Asta, M., Grolimund, D., FerreiraSánchez, D., Samson, V.A., Hunziker, D., Colas, V., González-Jiménez, J.M., Kerestedjian, T.N., Sergeeva, I., 2019, Diffusion pathways of $\mathrm{Fe}^{2+}$ and $\mathrm{Fe}^{3+}$ during the formation of ferrian chromite: a 
$\mu$ XANES study: Contributions to Mineralogy and Petrology, 174, 8, 65. https://doi. org/10.1007/s00410-019-1605-3

Geuna, S.E., Escosteguy, L.D., Miró, R., 2008, Palaeomagnetism of the Late DevonianEarly Carboniferous Achala Batholith, Córdoba, central Argentina: implications for the apparent polar wander path of Gondwana: Gondwana Research, 13, 2, 227-237. https://doi.org/10.1016/j. gr.2007.05.006

González-Jiménez, J.M., Griffin, W.L., Proenza, J.A., Gervilla, F., O’Reilly, S.Y., Akbulut, M., Pearson, N.J., Arai, S., 2014, Chromitites in ophiolites: how, where, when, why? Part II. The crystallization of chromitites: Lithos, 189, 140-158. https://doi.org/10.1016/j. lithos.2013.11.017

González-Jiménez, J.M., Reich, M., Camprubí, A., Gervilla, F., Griffin, W.L., Colás, V., O'Reilly, S.Y., Proenza, J.A., Pearson, N.J., Centeno-García, E., 2015, Thermal metamorphism of mantle chromites and the stability of noble-metal nanoparticles: Contributions to Mineralogy and Petrology, 170, 2, 1-20. https://doi.org/10.1007/ s00410-015-1169-9

González-Jiménez, J.M., Barra, F., Garrido, L.N.F., Reich, M., Satsukawa, T., Romero, R., Salazar, E., Colás, V., Orellana, F., Rabbia, O., Plissart, G., Morata, D., 2016, A secondary precious and base metal mineralization in chromitites linked to the development of a Paleozoic accretionary complex in Central Chile: Ore Geology Reviews, 78, 14-40. https://doi. org/10.1016/j.oregeorev.2016.02.017

González-Jiménez, J.M., Proenza, J.A., Martini, M., Camprubí, A., Griffin, W.L., O’Reilly, S.Y., Pearson, N.J., 2017, Deposits associated with ultramafic-mafic complexes in Mexico: the Loma Baya case: Ore Geology Reviews, 81, 1053-1065. https://doi.org/10.1016/j. oregeorev.2015.05.014

González-Jiménez, J.M., Colás, V., Gervilla, F., Kerestedjian, T.N., Sergeeva, I.,
Casado-González, A., Fanlo, I., 2018, Metamorphic evolution of sulphide-rich chromitites from the Ghernichevo ultramafic massif, SE Bulgaria: Ore Geology Reviews, 101, 330-348.https://doi.org/10.1016/j. oregeorev.2018.07.024

González-Mancera, G., Ortega-Gutiérrez, F., Proenza, J.A., Atudorei, V., 2009, Petrology and geochemistry of Tehuitzingo serpentinites (Acatlán Complex, SW Mexico): Boletín de la Sociedad Geológica Mexicana, 61, 3, 419-435. https://doi.org/10.18268/ bsgm2009v61n3a9.

Griffin, W.L., Afonso, J.G., Belousova, E., Gain, S.E., Gong, X.H., González-Jiménez, J.M., Howell, D., Huang, J.X., McGowan, N.M., Pearson, N.J., 2016, Mantle Recycling: Transition Zone Metamorphism of Tibetan Ophiolitic Peridotites and Its Tectonic Implications: Journal of Petrology, 57, 4, 655684. https://doi.org/10.1093/petrology/egw01 1

Guereschi, A.B., Martino, R.D., 2008, Field and textural evidence of two migmatization events in the Sierras de Córdoba, Argentina: Gondwana Research, 13, 2, 176-188. https://doi.org/10.1016/j.gr.2007.07.005

Hey, M.H., 1954, A new review of the chlorites: Mineralogical Magazine and Journal of the Mineralogical Society, 30, 224, 277-292. https://doi.org/10.1180/ minmag.1954.030.224.01

Holland, T.J.B., Powell, R., 1998, An internally consistent thermodynamic data set for phases of petrological interest: Journal of MetamorphicGeology, 16,3,309-343.https:/ / doi.org/10.1111/j.1525-1314.1998.00140.x

Irvine, T. N., 1967, Chromian spinel as a petrogenetic indicator: Part 2. Petrologic applications: Canadian Journal of Earth Sciences, 4(1), 71-103. https://doi. org/10.1139/e67-004

Jan, M.Q., Khan, M.A., Windley, B.F., 1992, Exsolution in $\mathrm{Al}-\mathrm{Cr}-\mathrm{Fe}^{\wedge} 3^{\wedge}$-rich spinels from the Chilas mafic-ultramafic complex, Pakistan: American Mineralogist, 77, 1074-1074. 
Kamenetsky, V.S., Crawford, A.J., Meffre, S., 2001, Factors controlling chemistry of magmatic spinel: an empirical study of associated olivine, Cr-spinel and melt inclusions from primitive rocks: Journal of Petrology, 42, 4, 655-671. https://doi.org/10.1093/ petrology/42.4.655

Kapsiotis, A., Rassios, A.E., Uysal, I., Grieco, G., Akmaz, R.M., Saka, S., Bussolesi, M., 2018, Compositional fingerprints of chromian spinel from the refractory chrome ores of Metalleion, Othris (Greece): Implications for metallogeny and deformation of chromitites within a "hot" oceanic fault zone: Journal of Geochemical Exploration, 185, 14-32. https://doi.org/10.1016/j. gexplo.2017.11.003

Kay, S.M., Gordillo, C.E., 1994, Pocho volcanic rocks and the melting of depleted continental lithosphere above a shallowly dipping subduction zone in the Central Andes: Contributions to Mineralogy and Petrology, 117, 1, 25-44. https://doi.org/10.1007/ bf00307727

Kingery, W.D., Bowen, H.K., Uhlmann, D.R., 1976, Introduction to ceramics, 2nd Ed.: A Wiley Publication, New York, 1056 p.

Lagorio, S.L., Vizán, H., Geuna, S.E., 2016, Early Cretaceous Volcanism in Central Argentina, in Anonymous Early Cretaceous Volcanism in Central and Eastern Argentina During GondwanaBreak-Up:Springer, 9-86.https:// doi.org/10.1007/978-3-319-29593-0_2

Leblanc, M., Nicolas, A., 1992, Ophiolitic chromitites: International Geology Review, 34, 7, 653-686. http://dx.doi. org/10.1080/00206819209465629

Loferski, P.J., 1986, Petrology of metamorphosed chromite-bearing ultramafic rocks from the Red Lodge District, Montana, in Anonymous Alexandria, USA, U.S. Government Printing Office, p. 34.

Majumdar, A.S., Hövelmann, J., Vollmer, C., Berndt, J., Mondal, S.K., Putnis, A., 2016, Formation of Mg-rich olivine pseudomorphs in serpentinized dunite from the Mesoarchean
Nuasahi Massif, Eastern India: Insights into the evolution of fluid composition at the mineral-fluid interface: Journal of Petrology, 57, 1, 3-26. https://doi.org/10.1093/ petrology/egv070

Martino, R.D., Kraemer, P.E., Escayola, M.P., Giambastiani, M., Arnosio, M., 1995, Transecta de las Sierras Pampeanas de Córdoba a los 32 S: Revista de la Asociación Geológica Argentina, 50, 1-4, 60-77.

Martino, R.D., 2003, Las fajas de deformación dúctil de las Sierras Pampeanas de Córdoba: Una reseña general: Revista de la Asociación Geológica Argentina, 58, 4, 549-571.

Martino, R.D., Guereschi, A.B., Anzil, P.A., 2010, Metamorphic and tectonic evolution at $31^{\circ}$ 36 ' $\mathrm{S}$ across a deep crustal zone from the Sierra Chica of Córdoba, Sierras Pampeanas, Argentina: Journal of South American Earth Sciences, 30, 1, 12-28. https://doi. org/10.1016/j.jsames.2010.07.008

Merlini, A., Grieco, G., and Diella, V., 2009, Ferritchromite and chromian-chlorite formation in mélange-hosted Kalkan chromitite (Southern Urals, Russia): American Mineralogist, 94, 10, 1459-1467. ttps://doi.org/10.2138/am.2009.3082

Ortiz-Hernández, L.E., Escamilla-Casas, J.C., Flores-Castro, K., Ramírez-Cardona, M., Acevedo-Sandoval, O., 2006, Características geológicas y potencial metalogenético de los principales complejos ultramáficos-máficos de México: Boletín de la Sociedad Geológica Mexicana, 58, 1, 161-181. https://doi. org/10.18268/bsgm2006v58nla6

Otamendi, J.E., Douce, P., Demichelis, A.H., 1999, Amphibolite to granulite transition in aluminous greywackes from the Sierra de Comechingones, Córdoba, Argentina: Journal of Metamorphic Geology, 17, 4, 415-434. https://doi. org/10.1046/j.1525-1314.1999.00208.x

Otamendi, J.E., Castellarini, P.A., Fagiano, M.R., Demichelis, A.H., Tibaldi, A.M., 2004, Cambrian to Devonian geologic evolution of the Sierra de Comechingones, Eastern 
Sierras Pampeanas, Argentina: evidence for the development and exhumation of continental crust on the Proto-Pacific margin of Gondwana: Gondwana Research, 7, 4, 1143-1155. https://doi.org/10.1016/ s1342-937x $(05) 71090-\mathrm{x}$

Otamendi, J.E., Tibaldi, A.M., Demichelis, A.H., Rabbia, O.M., 2005, Metamorphic evolution of the Río Santa Rosa Granulites, northern Sierra de Comechingones, Argentina: Journal of South American Earth Sciences, 18, 2, 163-181. https://doi.org/10.1016/j. jsames.2004.10.006

Padrón-Navarta, J.A., Hermann, J., Garrido, C.J., López Sánchez-Vizcaíno, V., GómezPugnaire, M.T., 2010, An experimental investigation of antigorite dehydration in natural silica-enriched serpentinite: Contributions to Mineralogy and Petrology, 159, 1, 25-42. https://doi.org/10.1007/ s00410-009-0414-5

Padrón-Navarta,J.A., López Sánchez-Vizcaíno, V., Hermann, J., Connolly, J.A.D., Garrido, C.J., Gómez-Pugnaire, M.T., Marchesi, C., 2013, Tschermak's substitution in antigorite and consequences for phase relations and water liberation in high-grade serpentinites: Lithos, 178, 186-196. https://doi.org/10.1016/j. lithos.2013.02.001

Pagé, P., Barnes, S.J., 2009, Using trace elements in chromites to constrain the origin of podiform chromitites in the Thetford Mines ophiolite, Québec, Canada: Economic Geology, 104, 7, 997-1018. https://doi.org/10.2113/ gsecongeo.104.7.997

Pinotti, L.P., Coniglio, J.E., Esparza, A.M., D'Eramo, F.J., Llambias, E.J., 2002, Nearly circular plutons emplaced by stoping at shallow crustal levels, Cerro Aspero batholith, Sierras Pampeanas de Córdoba, Argentina: Journal of South American Earth Sciences, 15, 2, 251-265. https://doi.org/10.1016/ s0895-981 1(02)00033-0

Plissart, G., González-Jiménez, J.M., Garrido, L.N.F., Colas, V., Berger, J., Monnier, C., Diot,
H., Padrón-Navarta, J.A., 2019, Tectonometamorphic evolution of subduction channel serpentinites from South-Central Chile: Lithos, 336, 221-241. https://doi. org/10.1016/j.lithos.2019.03.023

Pouchou,J.L.,Pichoir,F., 1991, Quantitativeanalysis of homogeneous or stratified microvolumes applying the model PAP, in Heinrich, K.F.J., and Newbury, D.E., eds., Electron Probe Quantitation: Plenum Press, 31-75. https:// doi.org/10.1007/978-1-4899-2617-3_4

Prabhakar, N., Bhattacharya, A., 2013, Origin of zoned spinel by coupled dissolutionprecipitation and inter-crystalline diffusion: evidence from serpentinized wehrlite, Bangriposi, Eastern India: Contributions to Mineralogy and Petrology, 166, 4, 1047-1066. https://doi.org/10.1007/ s00410-013-0909-y

Proenza, J.A., Gervilla, F., Melgarejo, J.C., Revé, D., Rodríguez, G., 1998, Las cromititas ofiolíticas del yacimiento Mercedita (Cuba). Un ejemplo de cromitas ricas en $\mathrm{Al}$ en la zona de transición manto-corteza: Acta Geologica Hispanica, 33, 1-4, 179-212.

Proenza, J.A., Gervilla, F., Melgarejo, J.C., Bodinier, J.L., 1999, Al-and Cr-rich chromitites from the Mayarí-Baracoa ophiolitic belt (eastern Cuba); consequence of interaction between volatile-rich melts and peridotites in suprasubduction mantle: Economic Geology, 94, 4, 547-566. https:// doi.org/10.2113/gsecongeo.94.4.547

Proenza, J.A., Ortega-Gutiérrez, F., Camprubí, A., Tritlla, J., Elías-Herrera, M., ReyesSalas, M., 2004, Paleozoic serpentiniteenclosed chromitites from Tehuitzingo (Acatlán Complex, southern Mexico): a petrological and mineralogical study: Journal of South American Earth Sciences, 16, 8, 649-666. https://doi.org/10.1016/j. jsames. 2003.12.003

Proenza, J.A., Zaccarini, F., Escayola, M.P., Cábana, G., Schalamuk, A., Garuti, G., 2008, Composition and textures of chromite 
and platinum-group minerals in chromitites of the western ophiolitic belt from Pampean Ranges of Córdoba, Argentina: Ore Geology Reviews, 33, 1, 32-48. https://doi. org/10.1016/j.oregeorev.2006.05.009

Pujol-Solà, N., Proenza, J.A., García-Casco, A., González-Jiménez, J.M., Andreazini, A., Melgarejo, J.C., Gervilla, F., 2018, An alternative scenario on the origin of ultrahigh pressure (UHP) and super-reduced (SuR) minerals in ophiolitic chromitites: A case study from the Mercedita deposit (eastern Cuba): Minerals, 8, 10, 433. https:// doi.org/10.3390/min8100433

Ramos, V.A., Munizaga, F., Kay, S.M., 1991, El magmatismo Cenozoico a los $33^{\circ} \mathrm{S}$ de latitud: geocronología y relaciones tectónicas: $6^{\circ}$ Congreso Geológico Chileno, 892-896.

Ramos, V.A., Vujovich, G.I., Martino, R.D., Otamendi, J.E., 2010, Pampia: a large cratonic block missing in the Rodinia supercontinent: Journal of Geodynamics, 50, 3-4, 243-255. https://doi.org/10.1016/j. jog.2010.01.019

Rapela, C.W., Pankhurst, R.J., Casquet, C., Baldo, E., Saavedra, J., Galindo, C., Fanning, C.M., 1998, The Pampean Orogeny of the southern proto-Andes: Cambrian continental collision in the Sierras de Córdoba: Geological Society, London, Special Publications, 142, 1, 181-217. https://doi.org/10.1144/gsl. sp.1998.142.01.10

Rapela, C.W., Verdecchia, S.O., Casquet, C., Pankhurst, R.J., Baldo, E.G., Galindo, C., Murra, J.A., Dahlquist, J.A., Fanning, C.M., 2016, Identifying Laurentian and SW Gondwana sources in the Neoproterozoic to Early Paleozoic metasedimentary rocks of the Sierras Pampeanas: Paleogeographic and tectonic implications: Gondwana Research, 32, 193-212. https://doi.org/10.1016/j. gr.2015.02.010

Rapela, C.W., Pankhurst, R.J., Casquet, C., Dahlquist, J.A., Fanning, G.M., Baldo, E.G., Galindo, C., Alasino, P.H., Ramacciotti,
C.D., Verdecchia, S.O., 2018, A review of the Famatinian Ordovician magmatism in southern South America: evidence of lithosphere reworking and continental subduction in the early proto-Andean margin of Gondwana: Earth-Science Reviews, 187, 259-285. https://doi.org/10.1016/j. earscirev.2018.10.006

Rollinson, H.R., 2008, The geochemistry of mantle chromitites from the northern part of the Oman ophiolite: inferred parental melt compositions: Contributions to Mineralogy and Petrology, 156, 3, 273-288. https://doi. org/10.1007/s00410-008-0284-2

Sack,R.O., Ghiorso,M.S., 1991a, Chromian spinels as petrogenetic indicators: Thermodynamics and petrological applications: American Mineralogist, 76, 5-6, 827-847.

Sack, R.O., Ghiorso, M.S., 1991b, An internally consistent model for the thermodynamic properties of $\mathrm{Fe}-\mathrm{Mg}$-titanomagnetitealuminate spinels: Contributions to Mineralogy and Petrology, 106, 4, 474-505. https://doi.org/10.1007/bf00325108

Satsukawa, T., Piazolo, S., González-Jiménez, J.M., Colás, V., Griffin, W.L., O’Reilly, S.Y., Gervilla, F., Fanlo, I., Kerestedjian, T., Kerestedjian, T., 2015, Fluid-present deformation aids chemical modification of chromite: Insights from chromites from Golyamo Kamenyane, SE Bulgaria: Lithos, 228, 78-89. https://doi.org/10.1016/j. lithos.2015.04.020

Siegesmund, S., Steenken, A., Martino, R.D., Wemmer, K., De Luchi, M.G., Frei, R., Presnyakov, S., Guereschi, A.B., 2010, Time constraints on the tectonic evolution of the Eastern Sierras Pampeanas (Central Argentina): International Journal of Earth Sciences, 99, 6, 1199-1226. https://doi. org/10.1007/s00531-009-0471-z

Stowe, C.W., 1994, Compositions and tectonic settings of chromite deposits through time: Economic Geology, 89, 3, 528-546. https:// doi.org/10.2113/gsecongeo.90.7.2092 
Su, B., Chen, Y., Mao, Q., Zhang, D., Jia, L.H., Guo, S., 2019, Minor elements in olivine inspect the petrogenesis of orogenic peridotites: Lithos, 344, 207-216. https:// doi.org/10.1016/j.lithos.2019.06.029

Tamura, A., Arai, S., 2004, Inhomogeneous spinel in chromitite from the Iwanai-dake peridotite complex, Hokkaido, Japan: variations of spinel unmixing texture and chemical composition: Science reports of Kanazawa University, 48, 1, 9-29.

Tamura, A., Arai, S., 2005, Unmixed spinel in chromitite from the Iwanai-dake peridotite complex, Hokkaido, Japan: A reaction between peridotite and highly oxidized magma in the mantle wedge: American Mineralogist, 90, 2-3, 473-480. https://doi. org/10.2138/am.2005.1570

Tanner, D., McDonald, I., Harmer, R.E.J., Muir, D.D., Hughes, H.S.R., 2019, A record of assimilation preserved by exotic minerals in the lowermost platinum-group element deposit of the Bushveld Complex: The Volspruit Sulphide Zone: Lithos, 324, 584-608.https://doi.org/10.1016/j. lithos.2018.10.032

Tassinari, G.C.G., Castroviejo, R., Rodrigues, J.F., Acosta,J., Pereira, E., 2011, A Neoproterozoic age for the chromitite and gabbro of the Tapo ultramafic Massif, Eastern Cordillera, Central Peru and its tectonic implications: Journal of South American Earth Sciences, 32, 4, 429-437. https://doi.org/10.1016/j. jsames.2011.03.008

Uysal, I., Akmaz, R.M., Saka, S., Kapsiotis, A., 2016, Coexistence of compositionally heterogeneous chromitites in the AntalyaIsparta ophiolitic suite, SW Turkey: A record of sequential magmatic processes in the sub-arc lithospheric mantle: Lithos, 248,160-174.https://doi.org/10.1016/j. lithos.2016.01.021

Whitney, D.L., Evans, B.W., 2010, Abbreviations for names of rock-forming minerals:
American Mineralogist, 95, 1, 185-187. https://doi.org/10.2138/am.2010.3371

Wijbrans, G.H., Klemme, S., Berndt, J., Vollmer, C., 2015, Experimental determination of trace element partition coefficients between spinel and silicate melt: the influence of chemical composition and oxygen fugacity: Contributions to Mineralogy and Petrology, 169, 4, 1-33. https://doi.org/10.1007/ s00410-015-1128-5

Xiong, Q., Henry, H., Griffin, W.L., Zheng, J.P., Satsukawa, T., Pearson, N.J., O'Reilly, S.Y., 2017, High-and low-Cr chromitite and dunite in a Tibetan ophiolite: evolution from mature subduction system to incipient forearc in the Neo-Tethyan Ocean: Contributions to Mineralogy and Petrology, 172, 6, 45. https:// doi.org/10.1007/s00410-017-1364-y

Yao, S., 1999, Chemical composition of chromites from ultramafic rocks: application to mineral exploration and petrogenesis: Sydney, Australia, Macquarie University, 174 p.

Yu, H., Zhang, H.F., Zou, H.B., Yang, Y.H., 2019, Minor and trace element variations in chromite from the Songshugou dunites, North Qinling Orogen: Evidence for amphibolite-facies metamorphism: Lithos, 328, 146-158.https://doi.org/10.1016/j. lithos.2019.01.009

Zhang, L., Smyth, J.R., Kawazoe, T., Jacobsen, S.D., Qin, S., 2018, Transition metals in the transition zone: partitioning of $\mathrm{Ni}, \mathrm{Co}$, and $\mathrm{Zn}$ between olivine, wadsleyite, ringwoodite, and clinoenstatite: Contributions to Mineralogy and Petrology, 173, 7, 52. https://doi. org/10.1007/s00410-018-1478-x

Zhou, M.F., Robinson, P.T., Su, B.X., Gao, J.F., Li, J.W., Yang, J.S., Malpas, J., 2014, Compositions of chromite, associated minerals, and parental magmas of podiform chromite deposits: The role of slab contamination of asthenospheric melts in suprasubduction zone environments: Gondwana Research, 26, 1, 262-283. 